\title{
Review
}

\section{Cognitive Dysfunction in Huntington's Disease: Humans, Mouse Models and Molecular Mechanisms}

\author{
Albert Giralt $^{\mathrm{a}, \mathrm{b}, \mathrm{c}}$, Ana Saavedra ${ }^{\mathrm{a}, \mathrm{b}, \mathrm{c}}$, Jordi Alberch $^{\mathrm{a}, \mathrm{b}, \mathrm{c}}$ and Esther Pérez-Navarro ${ }^{\mathrm{a}, \mathrm{b}, \mathrm{c}, *}$ \\ ${ }^{a}$ Departament de Biologia Cel-lular, Immunologia i Neurociències, Facultat de Medicina, \\ Universitat de Barcelona, Barcelona, Spain \\ ${ }^{\mathrm{b}}$ Institut d'Investigacions Biomèdiques August Pi i Sunyer (IDIBAPS), Barcelona, Spain \\ ${ }^{\mathrm{c}}$ Centro de Investigación Biomédica en Red sobre Enfermedades Neurodegenerativas (CIBERNED), \\ Barcelona, Spain
}

\begin{abstract}
Huntington's disease (HD) is an autosomal dominant progressive neurodegenerative disorder due to an expanded $\mathrm{CAG}$ /polyglutamine repeat in the coding region of the huntingtin (htt) gene that causes the preferential degeneration of striatal neurons. Although HD is classically considered a motor disorder, cognitive decline manifests even before the appearance of motor symptoms, and reflects the impairment of additional neuronal populations, such as cortical and hippocampal neurons, in the presence of mutant htt (mhtt). Studies on cognitive dysfunction in HD patients have focused on the cortico-striatal pathway. Here we will describe that HD patients and mouse models share many cognitive defects. Alterations in hippocampal synaptic plasticity and function found in HD mouse models highlight that changes in the functioning of the hippocampal formation contribute to cognitive dysfunction in humans. The similarity between the cognitive dysfunction in HD patients and mouse models has helped to understand better how cognitive dysfunction takes place. Moreover, it validates the use of HD mice to study the molecular mechanisms involved in HD cognitive decline. Several studies in HD mouse models indicate that altered synaptic composition/function, deficient neurotrophic support, kinase/phosphatase imbalance, and transcription dysregulation play an important role in cognitive impairment. This knowledge opens the possibility of identifying relevant therapeutic targets to fight cognitive decline in HD. The finding that in HD many mechanisms are similarly altered in hippocampal and striatal neurons suggests the possibility of a common therapeutic strategy to ameliorate both cognitive and motor dysfunction.
\end{abstract}

Keywords: BDNF, CBP, hippocampus, LTD, LTP, PKA, striatum

\section{INTRODUCTION}

Huntingtin (htt) is expressed in almost all tissues, has a widespread distribution in the brain, its expression levels are similar in control individuals and in Huntington's disease (HD) patients, and there is no evidence

\footnotetext{
*Correspondence to: Esther Pérez-Navarro, Departament de Biologia Cel-lular, Immunologia i Neurociències, Facultat de Medicina, Universitat de Barcelona, Casanova 143, E-08036 Barcelona, Spain. Tel.: +34 934035284; Fax: +34 934021907; E-mail: estherperez@ub.edu.
}

of increased htt expression in the brain regions most affected in HD (reviewed by [1]). Thus, several celltype specific features likely play a role in rendering some neuronal populations more vulnerable to the toxic/malfunctioning effects of mutant htt (mhtt).

A remarkable feature of the brain is synaptic interaction. Given that altered neuronal connections are critical to the appearance of motor deficits, and cortical and striatal neuropathology [2,3], it is likely that HD pathology firstly occurs in synapses [4] as has been pointed out [5-7]. Cognitive dysfunction 
appears to be the most clear first symptom in HD patients, as well as in mouse models of the disease [8-10]. Cognition is highly related to synaptic function and plasticity, and mhtt is expressed in dendrites and synapses $[11,12]$. In fact, mhtt forms aggregates in those subcellular compartments [11]. Moreover, mhtt interacts with several pre- and post-synaptic proteins involved in vesicle transport, receptor internalization, and control of synaptic function [5]. Thus, several questions deserve attention: what is the main role of mhtt in cognitive dysfunction? By which mechanisms can mhtt modify neuronal plasticity leading to cognitive deficits? Is there any molecule or pathway more susceptible to be affected by mhtt, thereby contributing to cognitive decline? Here, we will present studies showing that cortical and striatal malfunctioning, as well as compromised hippocampal function play a role in cognitive impairment in HD patients. Furthermore, we will relate findings in HD humans and mouse models, and we will try to answer those questions by going over the molecular alterations described in HD mice that can underlie, or at least contribute to, cognitive disturbances in humans, as they can be relevant therapeutic targets to fight cognitive decline in HD.

\section{METHODOLOGICAL CONSIDERATIONS}

\section{Limitations of human studies}

Like other disorders, HD is characterized by a diversity of clinical presentations, rates of progression and responses to therapy, suggesting the existence of different subgroups and possible variations in the underlying pathological processes (reviewed by [13]). The heterogeneity of human patients can account for the discrepancies in the studies showing [14-17] or not [18-20] cognitive deficits in presymptomatic HD-gene carriers. In fact, significant differences in cognitive processes between controls and pre-symptomatic HD patients subgroups have been reported [21]. Moreover, it seems that cognitive and neuropsychological pre-clinical alterations in HD do not follow uniformly [17]. Additionally, discrepancies could also depend on the selected tests, and on the low number of subjects used in most of these studies. Regarding neuroimaging techniques, although they have provided essential data to the understanding of HD pathophysiology, there are still some methodological problems to face like individual differences in brain activation due to comorbidity and/or medication, while complex statistical calculations and fallacies in interpreting the results can lead to variability and differences in the conclusions [22-24].
It is also important to mention that some careless interpretations might have been carried out. Cognitive alterations in HD have often been related to corticostriatal dysfunction, while hippocampal impairment is usually obviated in the interpretation of human HD studies, and can also play an important role in those deficits (see below).

\section{Limitations of studies in HD mouse models}

Learning and memory tasks in rodents often involve not only cognitive function but also physical skills. So, in HD mouse models performance in the Morris water maze or acquisition of a motor skill could be influenced by deficiencies not directly related to altered cognition but to fatigue or changes in muscular strength. On the other hand, the generation of HD mouse models using distinct strain backgrounds increases the difficulty of interpreting and compelling findings. In addition, mhtt also differs between mouse models as some express only a portion of the mhtt protein, while others express full-length mhtt, which adds variability mainly in phenotype severity (HD mouse models are reviewed elsewhere; [25, 26]). However, despite these problems and caveats, behavioral tasks studied in rodents have been crucial to reveal many aspects of HD progression, and mouse models have helped to start uncovering the molecular pathways underlying cognitive impairment in HD.

As for human studies, there are some misinterpretations in studies evaluating conditioned motor learning in mice, which although is thought to be mainly mediated by cortico-striatal pathways, can also involve the hippocampus [27]. Similarly, visual discrimination learning, strongly affected in HD mice [28, 29], is usually related to the striatum, but hippocampal function can also be involved in this paradigm $[30,31]$.

\section{MULTIPLE MEMORY SYSTEMS AND THEIR INTERACTIONS}

We will briefly introduce the multiple memory systems since this will be useful to put the reader in context, and because some emerging ideas can help to understand how to integrate findings from studies in humans and in HD mouse models (for complete reviews see [32, 33]).

Classically, the acquisition of new motor skills, the development of instrumental behavior and the formation of habits is thought to involve the striatum. The frontal cortex (together with a cortico-striatal loop) has been implicated in working memory, attention, 
and planning of goal-directed behaviors. Finally, several forms of episodic and semantic memories depend on temporal structures like the hippocampus and entorhinal cortex (reviewed by [32-34]). However, it is now generally accepted that there is an interaction between striatal, cortical and hippocampal systems. Thus, the final cognitive outcome can depend on compensatory, competitive or cooperative interactions between systems (reviewed by [35-37]). Importantly, under pathological conditions these interactions become imbalanced, and the performance of one memory system can increase to compensate the functional alterations ongoing in another related system [38]. Given that the limits between memory systems are not so clear [39], cognitive impairment in HD patients can be more difficult to relate to specific neural systems than previously thought.

\section{COGNITIVE DYSFUNCTION IN HD}

Several studies in patients and in mouse models of HD have been carried out to identify cognitive deficits and evaluate their progression. Unfortunately, studies in humans have mainly focused on the cortico-striatal function, and less frequently on the hippocampal formation [13] or other brain regions. However, some cognitive tests/abilities involve hippocampal integrity in addition to cortico-striatal function. Evidences from studies in mouse models show that synaptic plasticity alterations are found, not only in striatum, but also in the hippocampus [40], which can explain the hippocampal-related cognitive impairment observed in these animals. In addition, alterations in synaptic plasticity or activity in other brain regions such as the thalamus [41, 42] could also account for cognitive decline observed in HD patients [43]. However, in the present review, we will focus on cortico-striatal and hippocampal synaptic plasticity and function. Table 1 summarizes the cognitive deficits found in HD mouse models that better correlate with those found in patients.

\section{HD patients}

In the following sections we will present studies regarding cognitive dysfunction in HD patients in whom impairment of the cortical and striatal function could be playing a main role, and data showing that hippocampal function is also compromised. Cognitive deficits will be classified according to their manifestation: before the onset of motor symptoms (pre-symptomatic individuals), or when motor
Table 1

Summary of the cognitive deficits found in HD mouse models that better correlate with those found in HD patients

\begin{tabular}{|c|c|c|c|}
\hline \multirow{2}{*}{$\begin{array}{l}\text { Cognitive alterations } \\
\text { Pre-symptomatic stage }\end{array}$} & \multirow{2}{*}{$\begin{array}{l}\text { HD patients } \\
\text { References }\end{array}$} & \multicolumn{2}{|c|}{ HD mice } \\
\hline & & Model & References \\
\hline \multirow[t]{2}{*}{ Lack of strategy-shifting } & {$[50]$} & $\mathrm{R} 6 / 1$ & [28] \\
\hline & & YAC128 & [82] \\
\hline \multirow[t]{3}{*}{ Procedural learning deficits } & [57] & $\mathrm{R} 6 / 1$ & {$[258]$} \\
\hline & & YAC128 & [82] \\
\hline & & Knock-in & [94] \\
\hline Deficiencies in motor learning & [49] & YAC128 & [82] \\
\hline Loss of executive function & [21] & $\mathrm{R} 6 / 2$ & [259] \\
\hline \multicolumn{4}{|l|}{ Early-middle stage } \\
\hline \multirow{2}{*}{$\begin{array}{l}\text { Loss of inhibition } \\
\text { in pre-pulse inhibition paradigm }\end{array}$} & [46] & $\mathrm{R} 6 / 2$ & [260] \\
\hline & & YAC128 & {$[82,87]$} \\
\hline \multirow[t]{3}{*}{ Decreased recognition memory } & {$[67,261]$} & $\mathrm{R} 6 / 1$ & {$[88,90]$} \\
\hline & & $\mathrm{R} 6 / 2$ & [88] \\
\hline & & Knock in & {$[91,132]$} \\
\hline \multirow[t]{3}{*}{ Spatial learning deficits } & {$[16,54]$} & $\mathrm{R} 6 / 1$ & [88] \\
\hline & & $\mathrm{R} 6 / 2$ & [29] \\
\hline & & Knock-in & [91] \\
\hline
\end{tabular}

symptoms are already evident (early-middle symptomatic patients). Cortico-striatal-related cognitive alterations seem to appear earlier and be more severe than those likely mediated by the hippocampus and related temporal structures. Thus, mhtt affects differentially distinct brain regions, indicating that there are complex interactions between the mutation and the molecular environment.

\section{Cortico-striatal dysfunction}

One of the most common and persistent cognitive deficits in HD patients at pre-symptomatic stages is a difficulty in tasks requiring a shift in strategy [14, 44]. Interestingly, this aberrant response may stem from an inability to inhibit the previously learned response, a process thought to be mediated by the striatum [45]. Reinforcing the idea that loss of inhibition could account for the strategy-shifting deficits observed in humans, it has been demonstrated that there are alterations in the pre-pulse inhibition paradigm in HD patients at early stages [46]. At pre-symptomatic stages, HD patients also show alterations in executive functions, verbal fluency [21, 47], procedural learning, planning, and explicit motor learning [14, 48, 49]. In early-stage symptomatic HD patients, there is also a deficit in discrimination learning and reversal learning, again arguing in favor of perseverance in learned responses [50]. Moreover, attention, acquisition of psychomotor skills, planning, executive functions and memory progressively decline [44, 51-53].

In middle symptomatic HD patients a widespread cognitive decline is observed in which executive 
function, verbal fluency, perceptual speed and reasoning are strongly affected [16, 54]. Finally, at more advanced stages, a sub-cortical dementia gradually develops, with alterations in several simple and complex cognitive functions involving slow information processing, decreased motivation, depression, apathy and personality changes $[55,56]$.

Impairment of the cortico-striatal function in HD patients is also supported by neuroimaging studies. A study using functional magnetic resonance imaging shows alterations in a serial reaction time task paradigm in HD pre-symptomatic individuals with respect to controls. These alterations correlate well with decreased activity in the frontal cortex, and the putamen is also consistently less activated in HD patients than in control individuals [57]. Executive function is impaired in early HD patients correlating with caudate and putamen atrophy [51, 58]. Mildstage HD patients show less activation of dorso- and ventro-lateral prefrontal cortex, left inferior parietal cortex and left putamen during a parametric verbal working memory task. This reduced activity correlates with a loss of grey matter in these brain regions, and with a lower accuracy in the performance of the task [59]. A reduction in blood flow in caudate, parietal and frontal cortex in middle-stage HD patients, as assessed by high resolution single photon emission computerized tomography, correlates well with poor performance in distinct neuropsychological cognitive tests [60]. Decreased dopamine binding in the striatum of mild to moderate-stage HD patients was also found to correlate with deficits in visuospatial skills, episodic memory, verbal fluency and reasoning [54].

\section{Dysfunction of the hippocampus and temporal structures}

To our knowledge, studies focusing on the hippocampal function in HD patients are lacking. However, some of the cognitive tasks used in human studies can involve the participation of the hippocampus and temporal lobe structures. For instance, spatial working memory, spatial recognition memory [61], object recognition memory $[62,63]$, episodic memories $[64,65]$, and some forms of associative learning [66] are, at least in part, regulated by the hippocampus.

Pre-symptomatic HD patients show no serious deficits in spatial working memory as they perform well tasks involving these cognitive abilities, although their latency to respond is higher than in controls [14]. On the other hand, pre-symptomatic HD-gene carriers show impairments in recognition memory [67]. In early-mild symptomatic HD patients, there are alterations in associative learning, pattern and spatial short-term memory and in spatial working memory [68]. Although the authors suggested a role for the cortico-striatal circuitry, they did not mention that alterations in the hippocampus and related structures could be also involved. At this stage of the disease, deficits in recall and recognition memory are consistent and clear [69]. In middle-stage HD patients, a rather global cognitive decline is observed including episodic memory and spatial memory deficits $[16,54]$. Finally, at more advanced stages, there is a so-called subcortical dementia, with alterations in several cognitive functions, some of them likely involving impairment of the hippocampal function [55, 56]. Thus, tasks relying on hippocampal and cortico-temporal integrity (declarative memories: visuospatial, spatial workingmemory and object and spatial perception/recognition) are altered in HD patients but to a lesser extent than those dependent on cortico-striatal integrity (procedural learning). This is supported by the finding that, when HD patients have to solve a cognitive task, the hippocampus, which is less impaired, attempts to compensate for striatal dysfunction [70]. It is noteworthy to mention that, according to findings from distinct verbal learning tasks involving the hippocampal function [71], it has been suggested that, in HD, long-term memory is more prone to be affected than short-term memory [13, 16, 72-74].

Interestingly, tests assessing episodic memory and visuomotor abilities significantly correlate with metabolic reductions in temporal cortices [75]. Reductions in dopamine binding have also been correlated with deficits in the Stroop, Digit span and Tower of London tests [76]. Thus, imaging studies also provide evidences that alterations in the temporal region contribute to cognitive defects in HD patients.

\section{HD mouse models}

\section{Cortico-striatal impairment}

Several cognitive tasks can be used to evaluate cortico-striatal function in rodents as for example delayed-alternation tasks, discrimination tasks, procedural learning tasks and acquisition of new motor skills [77-79]. Performance in delayed-alternation tasks, which are highly dependent on cortico-striatal integrity [78], is strongly affected in HD mouse models at early ages: 5 week-old R6/2 [29], 10 week-old R6/1 [28] and 12 month-old knock-in mice [80]. Furthermore, visual discrimination learning [28, 29], as well as tactiledependent learning [81], is altered in pre-symptomatic R6 mice. In addition, alterations in strategy-shifting, 
a paradigm that can reveal aberrant perseverance on a learned response, are one of the most obvious presymptomatic deficits in both exon- 1 and full-length HD mouse models [28, 29, 82].

\section{Hippocampal dysfunction}

Several tasks involving hippocampal and related temporal structures, such as the Morris water maze [83], spontaneous alternation task [84, 85], and novel object recognition test [86], have been used to evaluate learning and memory in HD mouse models. Spatial learning and navigation are altered at pre-symptomatic stages in R6/1, R6/2, YAC128 and $\mathrm{Hdh}^{\mathrm{Q} 7 / \mathrm{Q} 111}$ mice [29, 87-90]. Moreover, object and spatial recognition memories are also impaired in pre-symptomatic R6/1, R6/2 and Hdh ${ }^{\mathrm{Q} 7 / \mathrm{Q} 111}$ mice [88, 90, 91]. These impairments persist during disease progression [92, 93]. However, exon-1 mouse models often display a rapid and severe phenotype progression, which does not allow distinguishing the onset of cortico-striatalrelated cognitive deficits from those related to the hippocampus. The use of knock-in mice has partially elucidated this question since alterations in corticostriatal-dependent cognitive tasks, involving delayed alternation and attention, have earlier onset [80, 94, 95] than changes in hippocampal-dependent cognitive tasks such as spatial learning [91]. In agreement with human data, some declarative long-term memories are earlier and more severely altered than short-term memories in both exon-1 and full-length HD mouse models [88, 90, 91, 96]. Furthermore, hippocampusbased learning skills are preserved in R6/2 mice at ages in which striatum-based learning is impaired [97], and hippocampal function can overcome deficits in striatal function [98]. Thereby, compensatory mechanisms operate so that less affected hippocampus balances striatal failure in HD.

\section{SYNAPTIC PLASTICITY ALTERATIONS IN HD MOUSE MODELS}

Activity-dependent modifications in synaptic efficacy (synaptic plasticity), such as long-term potentiation (LTP) and long-term depression (LTD), are widely believed to underlie information processing and storage in the brain [99] (for a comprehensive historic overview on LTP and LTD research see $[100,101])$. Here, we will present the most relevant findings regarding cortico-striatal and hippocampal plasticity alterations in HD mice. It is intriguing that whereas human studies have focused on cortico-striatal dysfunction to explain cognitive alterations in HD, researchers using mouse models have mainly focused on hippocampal function and related areas. Accordingly, the hippocampus is the brain region in which almost all synaptic plasticity changes have been described, and whose clear anatomical organization makes its study easy and comfortable. Studies in HD mice have provided several evidences that hippocampal function is strongly affected suggesting that many findings in HD patients could be related to this disturbance. This is relevant because hippocampal, cortical and striatal systems interact to regulate cognitive function.

\section{Cortico-striatal pathway}

Electrophysiological studies in cortico-striatal slices from HD mouse models have revealed, in general, earlier and more severe alterations in these connections than in hippocampal synapses [40, 102]. However, the progression of cortico-striatal deficiencies seems to be biphasic. In fact, $\mathrm{Ca}^{2+}$ currents in medium-sized spiny neurons (MSNs) are increased in young R6/2 mice, whereas they decrease in symptomatic transgenic mice [103-106]. Interestingly, a propensity towards corticostriatal synaptic depression is also observed in YAC mice [107]. Studies in different HD mouse models showed that glutamatergic transmission is either increased or decreased respect to wild-type mice [103, 108-110]. In YAC mice, this biphasic effect seems to correlate with an enhanced N-methyl-D-aspartate receptor (NMDAR) response at early ages that then dramatically decreases with age [111], indicating that each phenomenon occurs at different stages of the disease. On the other hand, evoked synaptic responses and spontaneous synaptic currents are both altered in the cortico-striatal pathway, and these alterations get worse as the neurological phenotype advances in HD mice [40].

Some studies have addressed cortical synaptic plasticity in pre-symptomatic HD animals. The study of the representation of the row of vibrissae after associative learning indicates that R6/1 mice display deficits in plasticity in the primary somatosensory cortex [112]. Other studies found deficits in cortical LTP [113-115], which could be rescued by dopamine receptor 1 activation [115]. At relative middle stage of the disease, cortico-striatal LTP is impaired in R6/2 mice [116], a defect that is still present in advanced stages [117]. Furthermore, the inability of cholinergic interneurons to display LTP could facilitate the dysfunction of striatal projecting neurons (reviewed by [118]). At later 
symptomatic ages, there is a progressive loss of cell capacitance of MSNs in exon-1 mouse models [103, 109, 119]. This correlates with a loss of corticostriatal synaptic markers, reduction of dendritic spines, reduced synaptic transmission, and with an inability to express cortico-striatal LTP in the dorsal striatum [116, $117,119,120]$.

\section{Hippocampal pathways}

Assessment of hippocampal function has shown that basal neurotransmission at hippocampal synapses (CA3-CA1 field excitatory post-synaptic potentials) appears normal, whereas LTP is reduced in transgenic $[28,121]$ and knock-in $[122,123]$ mouse models of HD. A decrease in mossy fiber potentiation was also reported in R6/2 mice [124]. However, at advanced ages, intrinsic membrane properties and action potentials are also altered in R6/1 hippocampal neurons [125], a phenomenon that occurs earlier in striatal neurons [40]. The alteration of the intrinsic electrophysiological properties of hippocampal neurons appears later than LTP and LTD deficits suggesting that neuronal plasticity dysfunction is synaptic in origin. Interestingly, YAC72 mice also show LTP deficits which consist of LTD instead of LTP expression as the disease progresses [126]. Related to this, abnormalities in hippocampal LTD expression seem to be the most conspicuous alteration in different exon-1 HD mouse models [121, 125]. On the other hand, paired pulse facilitation studies indicate that synaptic plasticity deficits observed in full-length [126], as well as in exon-1 [121] mouse models, are mainly due to post-synaptic dysfunction, although a pre-synaptic component should not be ruled out [5]. Considering all these findings, it could be assumed that persistence of synaptic depression is the most conspicuous hippocampal synaptic plasticity alteration, although LTP is also impaired. Moreover, the onset of neuronal plasticity deficits occurs earlier than the development of an overt phenotype, independent of normal synaptic transmission. Finally, a post-synaptic component more than a pre-synaptic component seems to play a main role in those alterations.

\section{MOLECULES AND PATHWAYS IMPLICATED IN COGNITIVE DECLINE IN HD: LESSONS FROM ANIMAL MODELS}

Cognition is highly dependent on plasticity processes in which proper synaptic function plays an important role. Thus, in order to design therapeutic
Table 2

Putative molecules contributing to cognitive deficits in HD mice

\begin{tabular}{|c|c|c|c|c|}
\hline Protein & $\begin{array}{l}\text { Brain } \\
\text { region }\end{array}$ & $\begin{array}{l}\text { Mouse } \\
\text { model }\end{array}$ & $\begin{array}{l}\text { Type of } \\
\text { alteration }\end{array}$ & References \\
\hline \multirow[t]{2}{*}{ PSD-95 } & Striatum & $\mathrm{R} 6 / 1$ & Reduced levels & [128] \\
\hline & Hippocampus & & Reduced levels & [90] \\
\hline GluA1 & Hippocampus & $\mathrm{R} 6 / 1$ & Reduced levels & [90] \\
\hline Complexin-II & $\begin{array}{l}\text { I Striatum } \\
\text { Cortex } \\
\text { Hippocampus }\end{array}$ & $\mathrm{R} 6 / 2$ & Reduced levels & [149] \\
\hline Synapsin I & $\begin{array}{l}\text { Cortex } \\
\text { Striatum }\end{array}$ & $\mathrm{R} 6 / 2$ & $\begin{array}{l}\text { Altered } \\
\text { phosphorylation } \\
\text { levels }\end{array}$ & [192] \\
\hline $\mathrm{NF}-\kappa \mathrm{B}$ & Forebrain & Knock-in & $\begin{array}{l}\text { Disrupted } \\
\text { synapse-nucleus } \\
\text { translocation }\end{array}$ & [262] \\
\hline $\begin{array}{l}\text { Dopamine } \\
\text { receptor } 1\end{array}$ & Striatum & $\mathrm{R} 6 / 2$ & $\begin{array}{l}\text { Reduced levels } \\
\text { and binding }\end{array}$ & [138] \\
\hline $\begin{array}{l}\text { Dopamine } \\
\text { receptor } 2\end{array}$ & Striatum & $\mathrm{R} 6 / 2$ & $\begin{array}{l}\text { Reduced levels } \\
\text { and binding }\end{array}$ & [138] \\
\hline
\end{tabular}

This table depicts several molecules involved in synaptic plasticity and in learning and memory that have been studied in HD mouse models, but whose alterations have not been directly related to the progression of cognitive decline. The aim is to show potential new therapeutic targets to fight cognitive impairments in HD.

approaches to treat cognitive impairment in $\mathrm{HD}$ it is essential to know the molecular alterations that can underlie, or at least contribute to, cognitive disturbances in HD patients. In the next sections we will focus on molecules/pathways involved in synaptic function and plasticity processes that have been shown to be sensitive to the presence of mhtt (Table 2). We will also discuss those that have been demonstrated to be involved in cognitive decline in HD models.

\section{Synaptic molecules}

In this section we will go through the changes in synaptic components described in HD that likely contribute to synaptic plasticity defects and cognitive impairment.

At early stages of the disease, when cognitive and plasticity alterations are detected, no changes in the protein levels of any NMDAR subunit are observed in the striatum of HD mouse models [127, 128]. Only a loss of striatal GluN2B subunit has been described in R6/1 mice at late stages of the disease [128]. Conversely, the function of NMDARs is severely altered in HD models [103]. The fact that HD mouse models do not respond to intrastriatal NMDAR agonists [111, 127-130] further supports the idea that intracellular signaling pathways activated by the receptor are affected in HD, which likely contributes to synaptic plasticity impairment and cortico-striatal-dependent cognitive defects. 
It is known for almost three decades that NMDARs are essential for the expression of hippocampal LTP [131], and the formation of hippocampal memory [83]. CA3-CA1 LTP deficits in full-length YAC72 and knock-in mice seem to be due, at least in part, to alterations in NMDARs $[122,126]$, while in R6/2 mice those deficits are NMDAR-independent [121]. Conversely, CA3-CA1 LTD deficits in R6/1 mice are dependent on GluN2B-containing NMDARs [125]. As for the striatum, no alterations in protein levels are observed for any NMDAR subunit in the hippocampus of R6/1 mice at early stages of the disease, when cognitive and plasticity alterations are detected [28], thus suggesting that hippocampal synaptic plasticity dysfunction dependent on NMDARs can be due to changes in downstream signaling.

It is noteworthy that in addition to NMDARs other glutamate receptors could play an important role in hippocampal synaptic dysfunction in HD. A good candidate is the $\alpha$-amino-3-hydroxyl5-methyl-4-isoxazole-propionate receptor (AMPAR) subunit GluA1 since it is early down-regulated in the hippocampus of HD mouse models [28, 90]. Interestingly, treatment with ampakines, drugs that enhance AMPARs' function, rescues LTP and object recognition memory in a knock-in mouse model of HD [132]. On the other hand, dopamine receptors, which are able to modulate synaptic plasticity in cortico-striatal and hippocampal connections (reviewed by [133]), are profoundly altered in the caudate-putamen of HD patients [76, 134-137], and in the striatum of mouse models [138-140] from very early stages of the disease. Actually, dopamine deficits can also contribute to LTD deficiencies reported in the perirhinal cortex [113], and to LTP defects found in the dorsal striatum [116], and in the prefrontal cortex [115] of HD transgenic mice.

In addition to receptors, alterations in scaffolding proteins are suitable to contribute to synaptic dysfunction in HD. To our knowledge, the most studied is post-synaptic density-95 (PSD-95). PSD-95 is a post-synaptic scaffold protein that stabilizes NMDARs and AMPARs [141, 142] and modulates their function [143]. Moreover, PSD95 anchors calcium/calmodulin-dependent protein kinase II (CaMKII), SynGAP and neuronal nitric oxide synthase [144, 145], and thus it is crucial for signaling downstream NMDARs. In HD mouse models PSD-95 is reduced in the striatum and hippocampus from very early stages [90, 127, 128]. Importantly, PSD-95 directly interacts with htt and polyglutamine expansions increase this interaction removing it from the synapse and altering neurotransmission [146]. On the other hand, loss of complexin-II, a protein that regulates fusion processes between synaptic vesicles and the plasma membrane [147], has been shown in PC12 cells expressing mhtt [148], in several brain regions of R6/2 mice, including the cortex, striatum and hippocampus [149], and in the striatum [150] and frontal cortex [151] of HD patients. Interestingly, and supporting a role for complexin-II reduction in HD cognitive impairment, complexin-II knockout mice display learning deficits [152], and impairment of LTP in the CA3 region of the hippocampus [124] similar to those observed in R6/2 mice.

Another emerging player in synaptic alterations is protein kinase $C$ and casein kinase substrate in neurons protein 1 (PACSIN1). PACSIN1 is a neurospecific phosphoprotein with a central role in synaptic vesicle and receptor recycling [153]. Aberrant interaction with mhtt removes PACSIN1 from the synapses in the cortex of pre-symptomatic and early-stage HD patients $[151,154]$, which likely limits its function in the stabilization of synaptic proteins and receptors. Given the dramatic changes in PACSIN1 found in HD patients, it would be relevant to study in mouse models whether they might contribute to synaptic plasticity alterations, and cognitive impairment.

\section{Brain-derived neurotrophic factor}

Brain-derived neurotrophic factor (BDNF), a member of the neurotrophin family, has emerged as an important regulator of synaptic plasticity, and several cognitive processes (reviewed by [155]). Interestingly, whereas htt positively regulates BDNF expression, mhtt impairs BDNF transcription and transport along axons and dendrites [156-160]. BDNF is highly expressed in the regions with highest dysfunction rates in HD (cortex, striatum and hippocampus), and striatal cells are highly dependent on BDNF for survival and function [161-163]. BDNF down-regulation is a widespread phenomenon in HD brain, observed in patients and in mouse models of the disease [28, 122, 164-166]. On the other hand, the BDNF high-affinity receptor TrkB is also reduced in HD models [167, 168 ], so the complete BDNF-TrkB system is strongly affected in HD. Given that BDNF/TrkB signaling enhances LTP induction not only in hippocampal neurons [169], but also in MSNs [170], their downregulation is expected to contribute to striatal [116, 171], as well as hippocampal [122, 123] LTP impairment described in HD models. Therefore, deficient BDNF signaling likely plays an important role in synaptic dysfunction, and learning and memory defects 
in HD. Actually, BDNF levels regulate the onset and severity of cognitive and motor symptoms, and synaptic plasticity deficits in HD mouse models [28, 122, 172]. Moreover, it has been shown that decreased activity-dependent BDNF expression contributes to cortical microcircuit hypo-connectivity in HD cells [173]. Interestingly, treatments focused on the recovery of BDNF levels successfully improve synaptic plasticity, and motor and cognitive functions in HD mouse models $[117,132,165,174]$.

By which mechanism can BDNF deficits alter synaptic plasticity and cognitive function? The BDNFTrkB system activates three main signaling pathways: the extracellular signal-regulated kinase 1/2 (ERK1/2) pathway, the phosphatidylinositol 3-kinase (PI3K)Akt pathway, and the phospholipase $\mathrm{C} \gamma$ (PLC $\gamma$ ) pathway (reviewed by [175]). ERK1/2 and Akt pathways are not altered in the hippocampus of R6/1 animals at early ages [88, 176, 177], when cognitive symptoms are already observed [28, 88]. Conversely, PLC $\gamma$ activity is strongly reduced in the hippocampus of young R6/1 mice [28]. These findings are relevant because the main effect of BDNF on LTP expression is basically modulated by the PLC $\gamma$ pathway $[178,179]$, and hippocampal LTP is impaired in HD mice.

\section{Kinase-phosphatase imbalance}

Memory formation and synaptic plasticity processes rely on balanced kinase and phosphatase activities [180-182]. Several phosphatases are altered in HD mouse models [183] and, most importantly, in the caudate/putamen of HD patients [135, 176, 184]. Strikingly, to our knowledge, their expression levels in post-mortem cortical and hippocampal samples from HD patients have not been analyzed. As many phosphatases altered in HD play a role in memory and plasticity, this imbalance likely contributes to synaptic alterations and cognitive impairment in HD.

Calcineurin plays an important role in synaptic plasticity, and learning and memory [185-189]. Interestingly, it is enriched in MSNs [190], and thus variations in its expression levels/activity can seriously alter their function. Calcineurin levels are reduced in R6 mice striatum [140, 184, 191, 192], and lower calcineurin activity has been shown in the striatum of YAC128 mice at 12 months of age [193]. Conversely, in R6/1 mice hippocampal calcineurin activity is unchanged from 4 to 30 weeks of age [88], and calcineurin levels are unaltered in the cortex [184]. Cortical calcineurin protein levels are also unaffected in $\mathrm{Hdh}^{\mathrm{Q} 111 / \mathrm{Q} 111}$ and $\mathrm{Hdh}^{\mathrm{Q} 111 / \mathrm{Q} 7}$ mice, but its activity is significantly higher than in $\mathrm{Hdh}^{\mathrm{Q} 7 / \mathrm{Q} 7}$ mice [194]. Thus, it is expected that alterations in calcineurin activity contribute to striatal, and possibly cortical, synaptic dysfunction in HD, while the hippocampus is likely not affected by changes in calcineurin levels/activity.

PHLPP (Pleckstrin homology (PH) domain leucinerich repeat protein phosphatase) $1 \alpha$ is reduced in the striatum of exon-1 and full-length HD mouse models [176]. Additionally, PHLPP1 $\alpha$ levels are also decreased in the cortex and hippocampus of R6/1 mice. Since PHLPP negatively regulates the Ras-Raf-MEK-ERK pathway [195], and participates in learning and memory [196], it is likely that those alterations in PHLPP levels can contribute to cognitive defects in HD, but this issue remains to be addressed.

STEP (striatal-enriched protein tyrosine phosphatase) plays an important role in synaptic plasticity through the opposition to synaptic strengthening, and alterations in STEP activity contribute to aberrant synaptic function and to cognitive impairment in several neuropsychiatric disorders [197]. We recently reported that R6/1 mice display reduced STEP protein levels in the striatum and cortex, and increased phosphorylation levels (increased inactivity) in the striatum, cortex and hippocampus [177]. Given that STEP is enriched in MSNs [198], and expressed at lower levels in the cortex, hippocampus and amygdala [199], aberrant STEP levels/activity, are likely to play a role in cognitive impairment in HD. Reduced STEP activity in HD can lead directly, or via the kinase Fyn, to increased activity of the NMDAR subunit 2B [200], which can possibly produce LTD [201]. Interestingly, R6 mice show an aberrant facilitation of LTD expression in the hippocampus by 3-4 months of age [125]. Despite all the evidences supporting a putative role for STEP in cognitive dysfunction in HD, this hypothesis remains to be tested.

Regardless of several supportive evidences, a role for the alterations of distinct phosphatases in the cognitive decline observed in HD remains to be directly demonstrated. In contrast, we recently showed that cognitive dysfunction in R6 mice correlates with increased hippocampal cAMP-regulated protein kinase (PKA) activity, as indicated by the hyperphosphorylation of several PKA substrates localized at the membrane [88]. PKA plays an important role in the expression of hippocampal-dependent memories [202]. In agreement, inhibition of hippocampal PKA hyper-activity reestablishes long-term recognition memory in $\mathrm{R} 6$ mice indicating that 
PKA-dependent processes are occluded in HD mice hippocampus [88]. Interestingly, we also reported a dysregulation of the PKA pathway in the striatum of R6/1 mice [177]. Of note, cAMP immunoreactivity is increased in the striatum of R6 mice [203, 204], and PKA substrates as GluN1 and STEP are hyper-phosphorylated in the striatum of exon-1 and/or full-length mouse models of HD at pre-symptomatic stages [128, 177]. Given the cognitive deficits found in striatal-dependent learning tasks in R6 mice [28, 29], it is tempting to speculate that aberrant PKA signaling can also contribute to this impairment.

Another kinase playing an important role in synaptic plasticity, and learning and memory is CaMKII [182, 205, 206]. To our knowledge, hippocampal CaMKII levels have not been analyzed in HD mouse models, but reduced levels have been found in the striatum [207] and cortex [208] of R6/2 mice at 6 weeks of age, and in the synaptic plasma membrane fraction of R6/1 striatum at 12 weeks of age [128]. Thus, these changes could contribute to synaptic plasticity alterations, and learning and memory defects in HD, but this issue needs to be directly addressed.

Summing up, alterations in kinase and phosphatase activities in HD are likely to contribute, directly or indirectly, to changes in relevant signaling pathways involved synaptic plasticity and activity-dependent gene transcription underlying learning and memory processes. Thus, kinases and phosphatases might be interesting therapeutic targets to investigate in the context of HD cognitive decline.

\section{Transcriptional dysfunction and cognitive impairment}

Consistent with mhtt interaction with several transcription factors, transcriptional dysregulation is a well-documented phenomenon in HD [209, 210]. Given that learning and memory depend not only on activity-dependent synaptic plasticity, but also on changes in neuronal gene expression [211, 212], it is likely that alterations in transcription pathways/machinery contribute to cognitive deficits in HD. cAMP-responsive element binding protein (CREB) plays a critical role in hippocampal-dependent synaptic plasticity and long-term memory [202, 213, 214]. Despite the aforementioned hyper-activity of PKA signaling [88], the phosphorylation levels of CREB, a nuclear PKA substrate, are not increased in the hippocampus of R6 mice [88]. Similarly, no changes in CREB phosphorylation levels were found in the hippocampus of $\mathrm{Hdh}^{\mathrm{Q} 7 / \mathrm{Q} 111}$ knock-in mice [91]. The transcriptional activity of CREB not only depends on CREB phosphorylation, but also on the recruitment of specific co-activators $[215,216]$. In contrast to the unaltered phosphorylation levels of CREB, the expression of the CREB co-activator CREB-binding protein (CBP), and of CREB/CBP target genes related to memory, such c-fos, Arc and Nr4a2, is reduced in the hippocampus of $\mathrm{Hdh}^{\mathrm{Q} 7 / \mathrm{Q} 111}$ mice [91]. Loss of $\mathrm{CBP}$ has also been shown in the striatum of HD mouse models, and improvement of CBP function is neuroprotective [217, 218]. Regarding to cognitive functions, mice heterozygous for CBP exhibit synaptic plasticity and memory deficits, as well as impaired rotarod performance [219], and mice with a mutation in the CREB-binding domain of CBP also have motor learning deficits [220]. These alterations are quite similar to those observed in HD mouse models. Besides being a CREB co-activator, CBP possesses histone acetyltransferase activity [221], which alters chromatin structure allowing gene transcription. Interestingly, treatment with a histone deacetylase inhibitor improves motor impairment in R6/2 mice [222], and memory deficits in $\mathrm{Hdh}^{\mathrm{Q} 7 / \mathrm{Q} 111}$ mice [91]. Given that altered CBP levels/function is a common feature in different HD brain regions, CBP could be a good therapeutic target for general cognitive improvement.

\section{THE TRIPARTITE SYNAPSE: A ROLE FOR ASTROCYTES IN HD COGNITIVE DECLINE?}

The idea that astrocytes could play an important role in plasticity and cognitive processes has been increasing [223-226]. Moreover, neuroimaging studies showing the precise coordination between the activities of neurons and astrocytes [227] suggest that findings from studies in humans might reveal neuronal as well as astrocytic dysfunction in HD.

In HD individuals, mhtt is also present in astrocytes [228], and expression of mhtt exclusively in astrocytes causes disease, although the progression is slower [229-231]. Moreover, the number of dendrites is reduced leading to neuronal atrophy [232]. With the "tripartite synapse" concept in mind [223-225], the aforementioned studies also suggest that mhtt expression in astrocytes could play a role in the alteration of synaptic plasticity in HD. Moreover, since cerebral blood flow is regulated by astrocytes (reviewed by [233]), the finding that pre-symptomatic HD patients already present resting decreased cerebral blood flow in the prefrontal cortex and putamen [234, 235] could indicate that there are early alterations in astrocytes in 
HD. Nevertheless, the precise role of astrocytes in cognitive decline in HD still warrants further investigation.

\section{THERAPEUTIC APPROACHES TO COGNITIVE IMPROVEMENT}

Nowadays, available therapies for HD include symptomatic treatments to improve motor dysfunction and depression, while treatments for cognitive symptoms have not yet been developed. So far, based on the assumption that an impairment of cholinergic pathways is also involved in cognitive dysfunction in HD (for review see [236, 237]), treatments used to ameliorate cognitive decline in HD patients are those used with the same purpose in other neurodegenerative disorders such as Alzheimer's disease. However, no improvements have been observed in HD patients treated with acetylcholinesterase inhibitors like donepezil [238, 239] and rivastagmine [240-242]. Conversely, a short-term administration of latrepirdine, a weak acetylcholinesterase inhibitor, has been shown to be well tolerated in HD patients, and to provide some beneficial effects on cognition, but further investigations are needed to prove its therapeutic efficacy [243].

Beside these therapeutic approaches, no other clinical trials have been designed to analyze whether drugs targeting molecular pathways involved in learning and memory [244] could be used to fight cognitive decline in HD. Therefore, there is a need to develop alternative strategies, and we have to take advantage from data obtained by analyzing HD mouse models. New therapeutic strategies can be developed based on altered molecular mechanisms leading to cognitive dysfunction (Fig. 1), and on pharmacological treatments showing benefits in mouse models. As discussed before, the BDNF trophic pathway is down-regulated in neurons affected in $\mathrm{HD}$, and consequently treatments focused on the recovery of BDNF levels improve both motor and cognitive deficits in several mouse models of the disease [117, 122, 165, 166, 172]. In addition, pharmacological treatments with molecules such as cystamine and cysteamine [245], CEP-1347 [246], sertraline [247, 248], ampakine [132, 174], rolipram [249] or TP-10 [250] have been shown to improve HD phenotype in mouse models, possibly by increasing endogenous BDNF levels. Interestingly, there are non-pharmacological approaches that improve BDNF levels, and that have already been shown to be beneficial in HD mouse models. Environmental enrichment induces beneficial effects in HD mouse models (reviewed by [251]) in part through increased expression of endogenous BDNF [252, 253]. Likewise, dietary restriction slows the progression of neuropathological, behavioral, and metabolic alterations, and increases BDNF levels in the striatum and cortex of HD mice [254]. Accumulated evidence indicates that sirtuins (Sirt), NAD-dependent protein deacetylases, are involved in the beneficial effects of caloric restriction [255]. Recently, Sirt1 was shown to prevent mhttinduced decline in BDNF levels [256], and BDNF was identified as a key target of Sirt1 transcriptional activity. While mhtt interferes with CREB-regulated transcriptional coactivator (CRTC) 1 (also known as transducer of regulated CREB activity, TORC1)CREB interaction to repress BDNF transcription, Sirt1 rescues this defect both in vitro and in vivo [257]. Thus, Sirt1 can be an additional therapeutic target to improve BDNF levels and cognitive function in HD.

Additional evidences of possible treatments to enhance cognition in HD come from studies showing alterations in hippocampal PKA activity in R6 animals [88], and in histone acetylation in knockin mice [91]. We have recently shown that PKA over-activation in the hippocampus contributes to longterm memory deficits in R6 mice [88]. In agreement, we observed that intra-hippocampal administration of a PKA inhibitor reestablishes long-term recognition memory [88]. Moreover, PKA over-activation is also observed in striatal cells expressing exon- $1 \mathrm{mhtt}$ [177], thus suggesting that inhibition of the PKA pathway could be also a good therapy to ameliorate motor symptoms. Decreased histone acetylation in the hippocampus has been shown to contribute to memory dysfunction in a knock-in mouse model of HD, and treatment with the HDAC inhibitor TSA reverses long-term memory impairments [91]. Interestingly, administration of HDAC inhibitors to HD mouse models has been shown to improve survival and motor performance in the rotarod, and to normalize striatal atrophy and prevent brain weight loss (reviewed by [217]). Thus, targeting PKA hyper-activity and histone hypo-acetylation in HD could serve to ameliorate cortico-striatal and hippocampal-dependent cognitive function, as well as motor symptoms.

\section{CONCLUSIONS AND FUTURE DIRECTIONS}

The study of the molecular mechanisms underlying cognitive dysfunction in HD mouse models demonstrates that many of the molecular pathways affected by mhtt are common to different types of neurons. Conversely, the real contribution of astrocytes to synaptic 

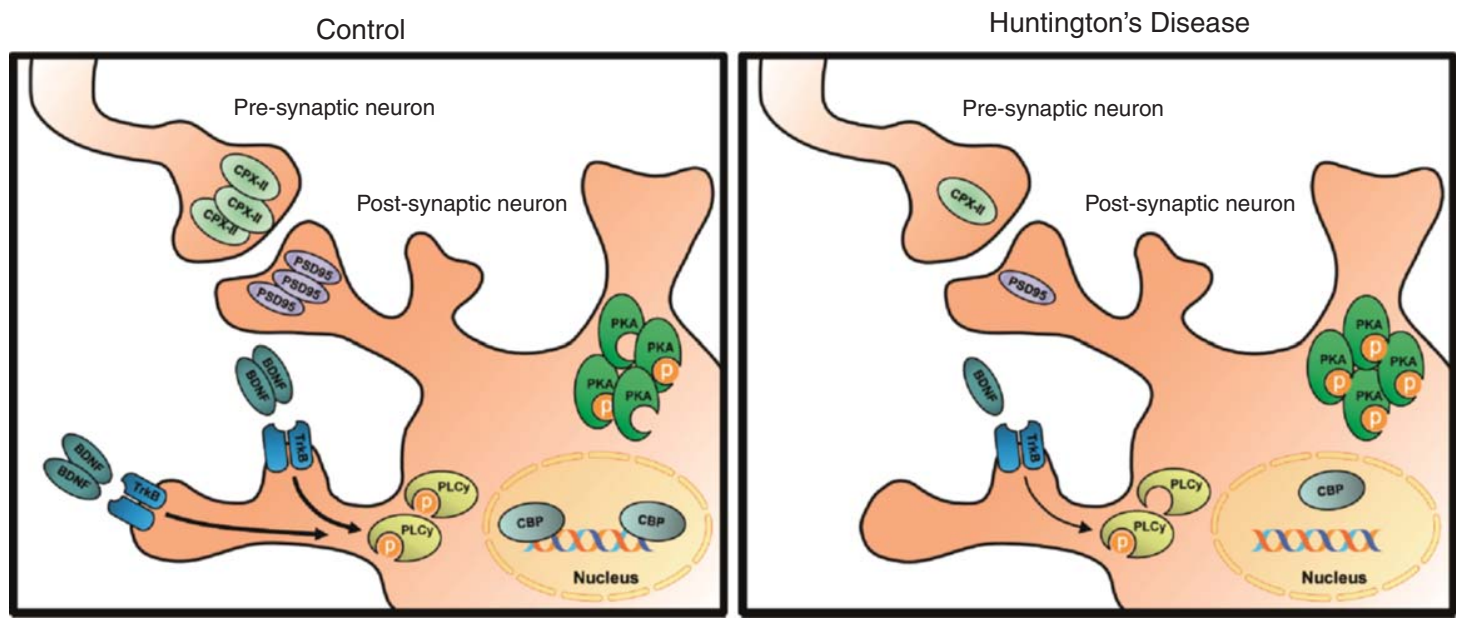

Fig. 1. Diagram showing putative therapeutic targets to improve cognitive decline in HD. Striatal- and hippocampal-related cognitive deficits in HD could be caused by alterations in different pathways. Control and HD conditions are depicted for comparisons. 1, Down-regulation of complexin-II could account for decreased pre-synaptic activity and function. 2, PSD-95 down-regulation and sequestration by mhtt could induce an aberrant downstream signaling mediated by glutamate synaptic receptors. 3, Aberrant PKA hyper-phosphorylation and activity would lead to a phenomenon of synaptic occlusion. 4, A dramatic decrease in the BDNF-TrkB system affects downstream signaling important for synaptic plasticity and memory via the PLCy pathway. 5, Decreased CBP levels prompt to transcriptional dysregulation and histone hypo-acetylation levels. Abbreviations: BDNF, brain-derived neurotrophic factor; CBP, CREB-binding protein; CPX-II, complexin-II; PKA, cAMP-regulated protein kinase; PLCy, phospholipase C-gamma; PSD-95, post-synaptic density-95; TrkB: tropomyosin receptor kinase B.

plasticity alterations, and to cognitive impairment in HD remains to be investigated. This knowledge will lead to therapeutic advances, as the possibility arises that the same treatment might improve both cognitive and motor symptoms. In this way, our future challenge is to design novel tools to treat cognitive symptoms in HD based on these findings. As cognitive deficits detected in mouse models resemble those observed in HD patients, this encourages the search of novel therapeutic approaches, as treatments that improve phenotype in mouse models should be also effective in the human pathology. In addition, it will also be important to test whether a pharmacological treatment is equally efficient when started either before or after cognitive and motor symptoms have appeared. Moreover, we consider that pharmacological treatments designed to improve only motor or cognitive symptoms should be revised in order to determine whether they are good therapeutic strategies to counteract both symptoms. Finally, as some of these treatments, in addition to ameliorate symptoms, are also neuroprotective it should be expected that they would stop or help to slow down the progression of the disease.

\section{ACKNOWLEDGMENTS}

Research in our group is supported by Fondo de Investigaciones Sanitarias (Instituto de Salud Carlos
III, PI10/01072 to E.P.-N.), Ministerio de Economia y Competitividad (Grant SAF2011-29507 to J.A.), and Generalitat de Catalunya (group of excellence; Grant 2009SGR-00326). A.G and A.S. are supported by Ministerio de Economia y Competitividad, grant CAPLE2009-0089 and Juan de la Cierva subprograme, Spain (JCI-2010-08207), respectively.

\section{CONFLICT OF INTEREST}

The authors declare that they have no conflict of interest.

\section{REFERENCES}

[1] Han I, You Y, Kordower JH, Brady ST, Morfini GA. Differential vulnerability of neurons in Huntington's disease: The role of cell type-specific features. J Neurochem. 2010;113(5):1073-91.

[2] Gu X, Li C, Wei W, Lo V, Gong S, Li SH, et al. Pathological cell-cell interactions elicited by a neuropathogenic form of mutant Huntingtin contribute to cortical pathogenesis in HD mice. Neuron. 2005;46(3):433-44.

[3] Gu X, Andre VM, Cepeda C, Li SH, Li XJ, Levine MS, et al. Pathological cell-cell interactions are necessary for striatal pathogenesis in a conditional mouse model of Huntington's disease. Mol Neurodegener. 2007;2:8.

[4] Nithianantharajah J, Hannan AJ. Dysregulation of synaptic proteins, dendritic spine abnormalities and pathological plasticity of synapses as experience-dependent mediators 
of cognitive and psychiatric symptoms in Huntington's disease. Neuroscience. 2012 (Epub ahead of print).

[5] Li JY, Plomann M, Brundin P. Huntington's disease: A synaptopathy? Trends Mol Med. 2003;9(10):414-20.

[6] Smith R, Brundin P, Li JY. Synaptic dysfunction in Huntington's disease: A new perspective. Cell Mol Life Sci. 2005;62(17):1901-12.

[7] van DA, Grote HE, Hannan AJ. Gene-environment interactions, neuronal dysfunction and pathological plasticity in Huntington's disease. Clin Exp Pharmacol Physiol. 2005;32(12):1007-19.

[8] Lichter DG, Hershey LA. Before chorea: Pre-Huntington mild cognitive impairment. Neurology. 2010;75(6):490-1.

[9] Paulsen JS. Cognitive impairment in Huntington disease: Diagnosis and treatment. Curr Neurol Neurosci Rep. 2011;11(5):474-83.

[10] Trueman RC, Dunnett SB, Brooks SP. Operant-based instrumental learning for analysis of genetically modified models of Huntington's disease. Brain Res Bull. 2012;88(2-3):261-75.

[11] Petrasch-Parwez E, Nguyen HP, Lobbecke-Schumacher M, Habbes HW, Wieczorek S, Riess O, et al. Cellular and subcellular localization of Huntingtin [corrected] aggregates in the brain of a rat transgenic for Huntington disease. J Comp Neurol. 2007;501(5):716-30.

[12] Suopanki J, Gotz C, Lutsch G, Schiller J, Harjes P, Herrmann A, et al. Interaction of huntingtin fragments with brain membranes-clues to early dysfunction in Huntington's disease. J Neurochem. 2006;96(3):870-84.

[13] Montoya A, Price BH, Menear M, Lepage M. Brain imaging and cognitive dysfunctions in Huntington's disease. $\mathbf{J}$ Psychiatry Neurosci. 2006;31(1):21-9.

[14] Lawrence AD, Weeks RA, Brooks DJ, Andrews TC, Watkins LH, Harding AE, et al. The relationship between striatal dopamine receptor binding and cognitive performance in Huntington's disease. Brain. 1998;121(Pt 7):1343-55.

[15] Lawrence AD, Hodges JR, Rosser AE, Kershaw A, ffrenchConstant C, Rubinsztein DC, et al. Evidence for specific cognitive deficits in preclinical Huntington's disease. Brain. 1998;121(Pt 7):1329-41.

[16] Lemiere J, Decruyenaere M, Evers-Kiebooms G, Vandenbussche E, Dom R. Cognitive changes in patients with Huntington's disease (HD) and asymptomatic carriers of the HD mutation-a longitudinal follow-up study. J Neurol. 2004;251(8):935-42.

[17] Snowden JS, Craufurd D, Thompson J, Neary D. Psychomotor, executive, and memory function in preclinical Huntington's disease. J Clin Exp Neuropsychol. 2002;24(2):133-45.

[18] Giordani B, Berent S, Boivin MJ, Penney JB, Lehtinen $\mathrm{S}$, Markel DS, et al. Longitudinal neuropsychological and genetic linkage analysis of persons at risk for Huntington's disease. Arch Neurol. 1995;52(1):59-64.

[19] Rothlind JC, Brandt J, Zee D, Codori AM, Folstein S. Unimpaired verbal memory and oculomotor control in asymptomatic adults with the genetic marker for Huntington's disease. Arch Neurol. 1993;50(8):799-802.

[20] Strauss ME, Brandt J. Is there increased WAIS pattern variability in Huntington's disease? J Clin Exp Neuropsychol. 1985;7(1):122-6.

[21] Hahn-Barma V, Deweer B, Durr A, Dode C, Feingold J, Pillon B, et al. Are cognitive changes the first symptoms of Huntington's disease? A study of gene carriers. J Neurol Neurosurg Psychiatry. 1998;64(2):172-7.
[22] Callicott JH, Weinberger DR. Neuropsychiatric dynamics: The study of mental illness using functional magnetic resonance imaging. Eur J Radiol. 1999;30(2):95-104.

[23] Holler Y, Kronbichler M, Zeller A, Klein S, Hinterhuber $\mathrm{H}$, Golaszewski S, et al. [Contribute of functional magnetic resonance imaging to the understanding of psychiatric disorders]. Neuropsychiatr. 2009;23(2):84-90.

[24] Walter H, Berger M, Schnell K. Neuropsychotherapy: Conceptual, empirical and neuroethical issues. Eur Arch Psychiatry Clin Neurosci. 2009;259(Suppl 2):S173-82.

[25] Ferrante RJ. Mouse models of Huntington's disease and methodological considerations for therapeutic trials. Biochim Biophys Acta. 2009;1792(6):506-20.

[26] Vonsattel JP. Huntington disease models and human neuropathology: Similarities and differences. Acta Neuropathol. 2008;115(1):55-69.

[27] Wise SP, Murray EA. Role of the hippocampal system in conditional motor learning: Mapping antecedents to action. Hippocampus. 1999;9(2):101-17.

[28] Giralt A, Rodrigo T, Martin ED, Gonzalez JR, Mila M, Cena V, et al. Brain-derived neurotrophic factor modulates the severity of cognitive alterations induced by mutant huntingtin: Involvement of phospholipaseC gamma activity and glutamate receptor expression. Neuroscience. 2009;158(4): 1234-50.

[29] Lione LA, Carter RJ, Hunt MJ, Bates GP, Morton AJ, Dunnett SB. Selective discrimination learning impairments in mice expressing the human Huntington's disease mutation. J Neurosci. 1999;19(23):10428-37.

[30] McDonald RJ, Jones J, Richards B, Hong NS. A double dissociation of dorsal and ventral hippocampal function on a learning and memory task mediated by the dorso-lateral striatum. Eur J Neurosci. 2006;24(6):1789-801.

[31] McDonald RJ, King AL, Wasiak TD, Zelinski EL, Hong NS. A complex associative structure formed in the mammalian brain during acquisition of a simple visual discrimination task: Dorsolateral striatum, amygdala, and hippocampus. Hippocampus. 2007;17(9):759-74.

[32] Kandel ER, Pittenger C. The past, the future and the biology of memory storage. Philos Trans R Soc Lond B Biol Sci. 1999;354(1392):2027-52.

[33] Thompson RF. In search of memory traces. Annu Rev Psychol. 2005;56:1-23.

[34] Thompson RF, Kim JJ. Memory systems in the brain and localization of a memory. Proc Natl Acad Sci U S A. 1996;93(24):13438-44.

[35] Gold PE. Coordination of multiple memory systems. Neurobiol Learn Mem. 2004;82(3):230-42.

[36] Hartley T, Burgess N. Complementary memory systems: Competition, cooperation and compensation. Trends Neurosci. 2005;28(4):169-70.

[37] White NM, McDonald RJ. Multiple parallel memory systems in the brain of the rat. Neurobiol Learn Mem. 2002; 77(2):125-84.

[38] Ghiglieri V, Sgobio C, Costa C, Picconi B, Calabresi P. Striatum-hippocampus balance: From physiological behavior to interneuronal pathology. Prog Neurobiol. 2011;94(2):102-14.

[39] Rossato JI, Zinn CG, Furini C, Bevilaqua LR, Medina JH, Cammarota M, et al. A link between the hippocampal and the striatal memory systems of the brain. An Acad Bras Cienc. 2006;78(3):515-23.

[40] Cepeda C, Wu N, Andre VM, Cummings DM, Levine MS The corticostriatal pathway in Huntington's disease. Prog Neurobiol. 2007;81(5-6):253-71. 
[41] Bellotti R, De CF, Massafra R, de TM, Sciruicchio V. Topographic classification of EEG patterns in Huntington's disease. Neurol Clin Neurophysiol. 2004;2004:37.

[42] Ehle AL, Stewart RM, Lellelid NA, Leventhal NA. Evoked potentials in Huntington's disease. A comparative and longitudinal study. Arch Neurol. 1984;41(4): 379-82.

[43] Kassubek J, Juengling FD, Ecker D, Landwehrmeyer GB Thalamic atrophy in Huntington's disease co-varies with cognitive performance: A morphometric MRI analysis. Cereb Cortex. 2005;15(6):846-53.

[44] Ho AK, Sahakian BJ, Brown RG, Barker RA, Hodges $\mathrm{JR}$, Ane MN, et al. Profile of cognitive progression in early Huntington's disease. Neurology 2003;61(12): $1702-6$

[45] Mink JW. The basal ganglia: Focused selection and inhibition of competing motor programs. Prog Neurobiol. 1996;50(4):381-425.

[46] Swerdlow NR, Paulsen J, Braff DL, Butters N, Geyer MA, Swenson MR. Impaired prepulse inhibition of acoustic and tactile startle response in patients with Huntington's disease. J Neurol Neurosurg Psychiatry. 1995;58(2):192-200.

[47] Paulsen JS, Zhao H, Stout JC, Brinkman RR, Guttman $\mathrm{M}$, Ross CA, et al. Clinical markers of early disease in persons near onset of Huntington's disease. Neurology. 2001;57(4):658-62.

[48] Rosenberg NK, Sorensen SA, Christensen AL. Neuropsychological characteristics of Huntington's disease carriers: A double blind study. J Med Genet. 1995;32(8):600-4.

[49] Schneider SA, Wilkinson L, Bhatia KP, Henley SM, Rothwell JC, Tabrizi SJ, et al. Abnormal explicit but normal implicit sequence learning in premanifest and early Huntington's disease. Mov Disord. 2010;25(10):1343-9.

[50] Lawrence AD, Sahakian BJ, Rogers RD, Hodge JR, Robbins TW. Discrimination, reversal, and shift learning in Huntington's disease: Mechanisms of impaired response selection. Neuropsychologia. 1999;37(12):1359-74.

[51] Bamford KA, Caine ED, Kido DK, Cox C, Shoulson I. A prospective evaluation of cognitive decline in early Huntington's disease: Functional and radiographic correlates. Neurology. 1995;45(10):1867-73.

[52] Heindel WC, Butters N, Salmon DP. Impaired learning of a motor skill in patients with Huntington's disease. Behav Neurosci. 1988;102(1):141-7.

[53] Watkins LH, Rogers RD, Lawrence AD, Sahakian BJ, Rosser AE, Robbins TW. Impaired planning but intact decision making in early Huntington's disease: Implications for specific fronto-striatal pathology. Neuropsychologia. 2000;38(8):1112-25.

[54] Backman L, Robins-Wahlin TB, Lundin A, Ginovart N, Farde L. Cognitive deficits in Huntington's disease are predicted by dopaminergic PET markers and brain volumes. Brain. 1997;120(Pt 12):2207-17.

[55] Paulsen JS, Butters N, Sadek JR, Johnson SA, Salmon DP, Swerdlow NR, et al. Distinct cognitive profiles of cortical and subcortical dementia in advanced illness. Neurology. 1995;45(5):951-6.

[56] Zakzanis KK. The subcortical dementia of Huntington's disease. J Clin Exp Neuropsychol. 1998;20(4):565-78.

[57] Kim JS, Reading SA, Brashers-Krug T, Calhoun VD, Ross CA, Pearlson GD. Functional MRI study of a serial reaction time task in Huntington's disease. Psychiatry Res. 2004;131(1):23-30.

[58] Peinemann A, Schuller S, Pohl C, Jahn T, Weindl A, Kassubek J. Executive dysfunction in early stages of
Huntington's disease is associated with striatal and insular atrophy: A neuropsychological and voxel-based morphometric study. J Neurol Sci. 2005;239(1):11-9.

[59] Wolf RC, Vasic N, Schonfeldt-Lecuona C, Ecker D, Landwehrmeyer GB. Cortical dysfunction in patients with Huntington's disease during working memory performance. Hum Brain Mapp. 2009;30(1):327-39.

[60] Hasselbalch SG, Oberg G, Sorensen SA, Andersen AR, Waldemar G, Schmidt JF, et al. Reduced regional cerebral blood flow in Huntington's disease studied by SPECT. J Neurol Neurosurg Psychiatry. 1992;55(11):1018-23.

[61] Kessels RP, de Haan EH, Kappelle LJ, Postma A. Varieties of human spatial memory: A meta-analysis on the effects of hippocampal lesions. Brain Res Brain Res Rev. 2001;35(3):295-303.

[62] Clarke JR, Cammarota M, Gruart A, Izquierdo I, DelgadoGarcia JM. Plastic modifications induced by object recognition memory processing. Proc Natl Acad Sci U S A. 2010;107(6):2652-7.

[63] Montaldi D, Mayes AR. The role of recollection and familiarity in the functional differentiation of the medial temporal lobes. Hippocampus. 2010;20(11):1291-314.

[64] Burgess N, Maguire EA, O'Keefe J. The human hippocampus and spatial and episodic memory. Neuron. 2002;35(4):625-41

[65] Eichenbaum H. Hippocampus: Cognitive processes and neural representations that underlie declarative memory. Neuron. 2004;44(1):109-20.

[66] Gruart A, Delgado-Garcia JM. Activity-dependent changes of the hippocampal CA3-CA1 synapse during the acquisition of associative learning in conscious mice. Genes Brain Behav. 2007;6(Suppl 1):24-31.

[67] Berrios GE, Wagle AC, Markova IS, Wagle SA, Rosser A, Hodges JR. Psychiatric symptoms in neurologically asymptomatic Huntington's disease gene carriers: A comparison with gene negative at risk subjects. Acta Psychiatr Scand. 2002;105(3):224-30.

[68] Lawrence AD, Watkins LH, Sahakian BJ, Hodges JR, Robbins TW. Visual object and visuospatial cognition in Huntington's disease: Implications for information processing in corticostriatal circuits. Brain. 2000;123(Pt 7):1349-64.

[69] Montoya A, Pelletier M, Menear M, Duplessis E, Richer F, Lepage M. Episodic memory impairment in Huntington's disease: A meta-analysis. Neuropsychologia. 2006;44(10): 1984-94.

[70] Voermans NC, Petersson KM, Daudey L, Weber B, Van Spaendonck KP, Kremer HP, et al. Interaction between the human hippocampus and the caudate nucleus during route recognition. Neuron. 2004;43(3):427-35.

[71] Rosazza C, Minati L, Ghielmetti F, Maccagnano E, Erbetta A, Villani F, et al. Engagement of the medial temporal lobe in verbal and nonverbal memory: Assessment with functional MR imaging in healthy subjects. AJNR Am J Neuroradiol. 2009;30(6):1134-41.

[72] Rohrer D, Salmon DP, Wixted JT, Paulsen JS. The disparate effects of Alzheimer's disease and Huntington's disease on semantic memory. Neuropsychology. 1999;13(3): 381-8.

[73] Wilson RS, Como PG, Garron DC, Klawans HL, Barr A, Klawans D. Memory failure in Huntington's disease. J Clin Exp Neuropsychol. 1987;9(2):147-54.

[74] Butters N. The clinical aspects of memory disorders: Contributions from experimental studies of amnesia and dementia. J Clin Neuropsychol. 1984;6(1):17-36. 
[75] Kuwert T, Lange HW, Langen KJ, Herzog H, Aulich A, Feinendegen LE. Cortical and subcortical glucose consumption measured by PET in patients with Huntington's disease. Brain. 1990;113(Pt 5):1405-23.

[76] Pavese N, Andrews TC, Brooks DJ, Ho AK, Rosser AE, Barker RA, et al. Progressive striatal and cortical dopamine receptor dysfunction in Huntington's disease: A PET study. Brain. 2003;126(Pt 5):1127-35.

[77] Brooks SP, Dunnett SB. Tests to assess motor phenotype in mice: A user's guide. Nat Rev Neurosci. 2009;10(7):519-29.

[78] Dunnett SB, Meldrum A, Muir JL. Frontal-striatal disconnection disrupts cognitive performance of the frontal-type in the rat. Neuroscience. 2005;135(4):1055-65.

[79] Fukabori R, Okada K, Nishizawa K, Kai N, Kobayashi K, Uchigashima $\mathbf{M}$, et al. Striatal direct pathway modulates response time in execution of visual discrimination. Eur J Neurosci. 2012;35(5):784-97.

[80] Trueman RC, Brooks SP, Jones L, Dunnett SB. Rule learning, visuospatial function and motor performance in the Hdh(Q92) knock-in mouse model of Huntington's disease. Behav Brain Res. 2009;203(2):215-22.

[81] Mazarakis NK, Cybulska-Klosowicz A, Grote H, Pang T, van DA, Kossut M, et al. Deficits in experience-dependent cortical plasticity and sensory-discrimination learning in presymptomatic Huntington's disease mice. J Neurosci. 2005;25(12):3059-66.

[82] Van Raamsdonk JM, Pearson J, Slow EJ, Hossain SM, Leavitt BR, Hayden MR. Cognitive dysfunction precedes neuropathology and motor abnormalities in the YAC128 mouse model of Huntington's disease. J Neurosci. 2005;25(16):4169-80.

[83] Morris RG, Anderson E, Lynch GS, Baudry M. Selective impairment of learning and blockade of long-term potentiation by an N-methyl-D-aspartate receptor antagonist, AP5. Nature. 1986;319(6056):774-6.

[84] Aggleton JP, Blindt HS, Rawlins JN. Effects of amygdaloid and amygdaloid-hippocampal lesions on object recognition and spatial working memory in rats. Behav Neurosci. 1989;103(5):962-74

[85] Gerlai R. A new continuous alternation task in T-maze detects hippocampal dysfunction in mice. A strain comparison and lesion study. Behav Brain Res. 1998;95(1):91-101.

[86] Broadbent NJ, Squire LR, Clark RE. Spatial memory, recognition memory, and the hippocampus. Proc Natl Acad Sci U S A. 2004;101(40):14515-20.

[87] Brooks S, Higgs G, Janghra N, Jones L, Dunnett SB. Longitudinal analysis of the behavioural phenotype in YAC128 (C57BL/6J) Huntington's disease transgenic mice. Brain Res Bull. 2012;88(2-3):113-20.

[88] Giralt A, Saavedra A, Carreton O, Xifro X, Alberch J, PerezNavarro E. Increased PKA signaling disrupts recognition memory and spatial memory: Role in Huntington's disease. Hum Mol Genet. 2011;20(21):4232-47.

[89] Luesse HG, Schiefer J, Spruenken A, Puls C, Block F, Kosinski CM. Evaluation of R6/2 HD transgenic mice for therapeutic studies in Huntington's disease: Behavioral testing and impact of diabetes mellitus. Behav Brain Res. 2001;126(1-2):185-95.

[90] Nithianantharajah J, Barkus C, Murphy M, Hannan AJ. Gene-environment interactions modulating cognitive function and molecular correlates of synaptic plasticity in Huntington's disease transgenic mice. Neurobiol Dis. 2008;29(3):490-504.

[91] Giralt A, Puigdellivol M, Carreton O, Paoletti P, Valero $\mathrm{J}$, Parra-Damas A, et al. Long-term memory deficits in
Huntington's disease are associated with reduced CBP histone acetylase activity. Hum Mol Genet. 2012;21(6):120316.

[92] Grote HE, Bull ND, Howard ML, van DA, Blakemore C Bartlett PF, et al. Cognitive disorders and neurogenesis deficits in Huntington's disease mice are rescued by fluoxetine. Eur J Neurosci. 2005;22(8):2081-8.

[93] Smith R, Chung H, Rundquist S, Maat-Schieman ML, Colgan L, Englund E, et al. Cholinergic neuronal defect without cell loss in Huntington's disease. Hum Mol Genet. 2006;15(21):3119-31.

[94] Trueman RC, Brooks SP, Jones L, Dunnett SB. Time course of choice reaction time deficits in the $\mathrm{Hdh}(\mathrm{Q} 92)$ knock-in mouse model of Huntington's disease in the operant serial implicit learning task (SILT). Behav Brain Res. 2008;189(2):317-24

[95] Trueman RC, Jones L, Dunnett SB, Brooks SP. Early onset deficits on the delayed alternation task in the $\operatorname{Hdh}(\mathrm{Q} 92)$ knock-in mouse model of Huntington's disease. Brain Res Bull. 2012;88(2-3):156-62.

[96] Dowie MJ, Howard ML, Nicholson LF, Faull RL, Hannan AJ, Glass M. Behavioural and molecular consequences of chronic cannabinoid treatment in Huntington's disease transgenic mice. Neuroscience. 2010;170(1):324-36.

[97] Ciamei A, Morton AJ. Rigidity in social and emotiona memory in the R6/2 mouse model of Huntington's disease. Neurobiol Learn Mem. 2008;89(4):533-44

[98] Ciamei A, Morton AJ. Progressive imbalance in the interaction between spatial and procedural memory systems in the R6/2 mouse model of Huntington's disease. Neurobiol Learn Mem. 2009;92(3):417-28.

[99] Bliss TV, Collingridge GL. A synaptic model of memory: Long-term potentiation in the hippocampus. Nature 1993;361(6407):31-9.

[100] Akhondzadeh S. Hippocampal synaptic plasticity and cognition. J Clin Pharm Ther. 1999;24(4):241-8.

[101] Bennett MR. The concept of long term potentiation of transmission at synapses. Prog Neurobiol. 2000;60(2):109-37.

[102] Milnerwood AJ, Raymond LA. Early synaptic pathophysiology in neurodegeneration: Insights from Huntington's disease. Trends Neurosci. 2010;33(11):513-23.

[103] Cepeda C, Ariano MA, Calvert CR, Flores-Hernandez J, Chandler SH, Leavitt BR, et al. NMDA receptor function in mouse models of Huntington disease. J Neurosci Res. 2001;5;66(4):525-39.

[104] Plotkin JL, Wu N, Chesselet MF, Levine MS. Functional and molecular development of striatal fast-spiking GABAergic interneurons and their cortical inputs. Eur J Neurosci. 2005;22(5):1097-108.

[105] Rebec GV, Conroy SK, Barton SJ. Hyperactive striatal neurons in symptomatic Huntington R6/2 mice: Variations with behavioral state and repeated ascorbate treatment. Neuroscience. 2006;137(1):327-36.

[106] Starling AJ, Andre VM, Cepeda C, de LM, Chandler SH, Levine MS. Alterations in N-methyl-D-aspartate receptor sensitivity and magnesium blockade occur early in development in the R6/2 mouse model of Huntington's disease. J Neurosci Res. 2005;82(3):377-86.

[107] Milnerwood AJ, Raymond LA. Corticostriatal synaptic function in mouse models of Huntington's disease: Early effects of huntingtin repeat length and protein load. J Physiol. 2007;585(Pt 3):817-31.

[108] Laforet GA, Sapp E, Chase K, McIntyre C, Boyce FM, Campbell M, et al. Changes in cortical and striatal neurons predict behavioral and electrophysiological abnormalities 
in a transgenic murine model of Huntington's disease. J Neurosci. 2001;21(23):9112-23.

[109] Levine MS, Klapstein GJ, Koppel A, Gruen E, Cepeda C, Vargas ME, et al. Enhanced sensitivity to N-methylD-aspartate receptor activation in transgenic and knockin mouse models of Huntington's disease. J Neurosci Res. 1999;58(4):515-32.

[110] Zeron MM, Hansson O, Chen N, Wellington CL, Leavitt $\mathrm{BR}$, Brundin $\mathrm{P}$, et al. Increased sensitivity to N-methyl-Daspartate receptor-mediated excitotoxicity in a mouse model of Huntington's disease. Neuron. 2002;33(6):849-60.

[111] Graham RK, Pouladi MA, Joshi P, Lu G, Deng Y, Wu NP, et al. Differential susceptibility to excitotoxic stress in YAC128 mouse models of Huntington disease between initiation and progression of disease. J Neurosci. 2009;29(7):2193-204.

[112] Cybulska-Klosowicz A, Mazarakis NK, van DA, Blakemore C, Hannan AJ, Kossut M. Impaired learning-dependent cortical plasticity in Huntington's disease transgenic mice. Neurobiol Dis. 2004;17(3):427-34.

[113] Cummings DM, Milnerwood AJ, Dallerac GM, Waights V, Brown JY, Vatsavayai SC, et al. Aberrant cortical synaptic plasticity and dopaminergic dysfunction in a mouse model of Huntington's disease. Hum Mol Genet. 2006;15(19):2856-68.

[114] Cummings DM, Milnerwood AJ, Dallerac GM, Vatsavayai SC, Hirst MC, Murphy KP. Abnormal cortical synaptic plasticity in a mouse model of Huntington's disease. Brain Res Bull. 2007;72(2-3):103-7.

[115] Dallerac GM, Vatsavayai SC, Cummings DM, Milnerwood AJ, Peddie CJ, Evans KA, et al. Impaired long-term potentiation in the prefrontal cortex of Huntington's disease mouse models: Rescue by D1 dopamine receptor activation. Neurodegener Dis. 2011;8(4):230-9.

[116] Kung VW, Hassam R, Morton AJ, Jones S. Dopaminedependent long term potentiation in the dorsal striatum is reduced in the R6/2 mouse model of Huntington's disease. Neuroscience. 2007;146(4):1571-80.

[117] Giralt A, Carreton O, Lao-Peregrin C, Martin ED, Alberch J. Conditional BDNF release under pathological conditions improves Huntington's disease pathology by delaying neuronal dysfunction. Mol Neurodegener. 2011;6(1):71.

[118] Di Filippo M, Tozzi A, Picconi B, Ghiglieri V, Calabresi P. Plastic abnormalities in experimental Huntington's disease. Curr Opin Pharmacol. 2007;7(1):106-11.

[119] Klapstein GJ, Fisher RS, Zanjani H, Cepeda C, Jokel ES, Chesselet MF, et al. Electrophysiological and morphological changes in striatal spiny neurons in R6/2 Huntington's disease transgenic mice. J Neurophysiol. 2001;86(6):266777.

[120] Guidetti P, Charles V, Chen EY, Reddy PH, Kordower JH, Whetsell WO Jr, et al. Early degenerative changes in transgenic mice expressing mutant huntingtin involve dendritic abnormalities but no impairment of mitochondrial energy production. Exp Neurol. 2001;169(2):340-50.

[121] Murphy KP, Carter RJ, Lione LA, Mangiarini L, Mahal A, Bates GP, et al. Abnormal synaptic plasticity and impaired spatial cognition in mice transgenic for exon 1 of the human Huntington's disease mutation. J Neurosci. 2000;20(13):5115-23.

[122] Lynch G, Kramar EA, Rex CS, Jia Y, Chappas D, Gall CM, et al. Brain-derived neurotrophic factor restores synaptic plasticity in a knock-in mouse model of Huntington's disease. J Neurosci. 2007;27(16):4424-34.

[123] Usdin MT, Shelbourne PF, Myers RM, Madison DV. Impaired synaptic plasticity in mice carrying the
Huntington's disease mutation. Hum Mol Genet. 1999;8(5): 839-46.

[124] Gibson HE, Reim K, Brose N, Morton AJ, Jones S. A similar impairment in CA3 mossy fibre LTP in the R6/2 mouse model of Huntington's disease and in the complexin II knockout mouse. Eur J Neurosci. 2005;22(7):1701-12.

[125] Milnerwood AJ, Cummings DM, Dallerac GM, Brown JY, Vatsavayai SC, Hirst MC, et al. Early development of aberrant synaptic plasticity in a mouse model of Huntington's disease. Hum Mol Genet. 2006;15(10):1690-703.

[126] Hodgson JG, Agopyan N, Gutekunst CA, Leavitt BR, LePiane F, Singaraja R, et al. A YAC mouse model for Huntington's disease with full-length mutant huntingtin, cytoplasmic toxicity, and selective striatal neurodegeneration. Neuron. 1999;23(1):181-92.

[127] Jarabek BR, Yasuda RP, Wolfe BB. Regulation of proteins affecting NMDA receptor-induced excitotoxicity in a Huntington's mouse model. Brain. 2004;127(Pt 3):505-16.

[128] Torres-Peraza JF, Giralt A, Garcia-Martinez JM, Pedrosa E, Canals JM, Alberch J. Disruption of striatal glutamatergic transmission induced by mutant huntingtin involves remodeling of both postsynaptic density and NMDA receptor signaling. Neurobiol Dis. 2008;29(3):409-21.

[129] Hansson O, Petersen A, Leist M, Nicotera P, Castilho RF, Brundin P. Transgenic mice expressing a Huntington's disease mutation are resistant to quinolinic acid-induced striatal excitotoxicity. Proc Natl Acad Sci U S A. 1999;96(15):872732.

[130] Hansson O, Guatteo E, Mercuri NB, Bernardi G, Li XJ, Castilho RF, et al. Resistance to NMDA toxicity correlates with appearance of nuclear inclusions, behavioural deficits and changes in calcium homeostasis in mice transgenic for exon 1 of the huntington gene. Eur J Neurosci. 2001;14(9):1492-504.

[131] Collingridge GL, Kehl SJ, McLennan H. The antagonism of amino acid-induced excitations of rat hippocampal CA1 neurones in vitro. J Physiol. 1983;334:19-31.

[132] Simmons DA, Rex CS, Palmer L, Pandyarajan V, Fedulov V, Gall CM, et al. Up-regulating BDNF with an ampakine rescues synaptic plasticity and memory in Huntington's disease knockin mice. Proc Natl Acad Sci U S A. 2009;106(12):4906-11.

[133] Jay TM. Dopamine: A potential substrate for synaptic plasticity and memory mechanisms. Prog Neurobiol. 2003;69(6):375-90.

[134] Augood SJ, Faull RL, Emson PC. Dopamine D1 and D2 receptor gene expression in the striatum in Huntington's disease. Ann Neurol. 1997;42(2):215-21.

[135] Hodges A, Strand AD, Aragaki AK, Kuhn A, Sengstag $\mathrm{T}$, Hughes $\mathrm{G}$, et al. Regional and cellular gene expression changes in human Huntington's disease brain. Hum Mol Genet. 2006;15(6):965-77.

[136] van Oostrom JC, Maguire RP, Verschuuren-Bemelmans CC, Veenma-van der Duin L, Pruim J, Roos RA, et al. Striatal dopamine $\mathrm{D} 2$ receptors, metabolism, and volume in preclinical Huntington disease. Neurology. 2005;65(6):941-3.

[137] Weeks RA, Piccini P, Harding AE, Brooks DJ. Striatal D1 and D2 dopamine receptor loss in asymptomatic mutation carriers of Huntington's disease. Ann Neurol. 1996;40(1):49-54.

[138] Cha JH, Kosinski CM, Kerner JA, Alsdorf SA, Mangiarini L, Davies SW, et al. Altered brain neurotransmitter receptors in transgenic mice expressing a portion of an abnormal human huntington disease gene. Proc Natl Acad Sci U S A. 1998;95(11):6480-5. 
[139] Desplats PA, Kass KE, Gilmartin T, Stanwood GD, Woodward EL, Head SR, et al. Selective deficits in the expression of striatal-enriched mRNAs in Huntington's disease. J Neurochem. 2006;96(3):743-57.

[140] Luthi-Carter R, Strand A, Peters NL, Solano SM, Hollingsworth ZR, Menon AS, et al. Decreased expression of striatal signaling genes in a mouse model of Huntington's disease. Hum Mol Genet. 2000;9(9):1259-71.

[141] Elias GM, Funke L, Stein V, Grant SG, Bredt DS, Nicoll RA. Synapse-specific and developmentally regulated targeting of AMPA receptors by a family of MAGUK scaffolding proteins. Neuron. 2006;52(2):307-20.

[142] Funke L, Dakoji S, Bredt DS. Membrane-associated guanylate kinases regulate adhesion and plasticity at cell junctions. Annu Rev Biochem. 2005;74:219-45.

[143] Xu W. PSD-95-like membrane associated guanylate kinases (PSD-MAGUKs) and synaptic plasticity. Curr Opin Neurobiol. 2011;21(2):306-12.

[144] Kim E, Sheng M. PDZ domain proteins of synapses. Nat Rev Neurosci. 2004;5(10):771-81.

[145] Sheng M, Sala C. PDZ domains and the organization of supramolecular complexes. Annu Rev Neurosci. 2001;24:1-29.

[146] Sun Y, Savanenin A, Reddy PH, Liu YF. Polyglutamineexpanded huntingtin promotes sensitization of N-methylD-aspartate receptors via post-synaptic density 95. J Biol Chem. 2001;276(27):24713-8.

[147] Rizo J, Sudhof TC. Snares and Munc18 in synaptic vesicle fusion. Nat Rev Neurosci. 2002;3(8):641-53.

[148] Edwardson JM, Wang CT, Gong B, Wyttenbach A, Bai J, Jackson MB, et al. Expression of mutant huntingtin blocks exocytosis in PC12 cells by depletion of complexin II. J Biol Chem. 2003;278(33):30849-53.

[149] Morton AJ, Edwardson JM. Progressive depletion of complexin II in a transgenic mouse model of Huntington's disease. J Neurochem. 2001;76(1):166-72.

[150] Morton AJ, Faull RL, Edwardson JM. Abnormalities in the synaptic vesicle fusion machinery in Huntington's disease. Brain Res Bull. 2001;56(2):111-7.

[151] DiProspero NA, Chen EY, Charles V, Plomann M, Kordower JH, Tagle DA. Early changes in Huntington's disease patient brains involve alterations in cytoskeletal and synaptic elements. J Neurocytol. 2004;33(5):517-33.

[152] Glynn D, Bortnick RA, Morton AJ. Complexin II is essential for normal neurological function in mice. Hum Mol Genet. 2003;12(19):2431-48.

[153] Wasiak S, Quinn CC, Ritter B, de HE, Baranes D, Plomann $\mathrm{M}$, et al. The Ras/Rac guanine nucleotide exchange factor mammalian Son-of-sevenless interacts with PACSIN 1/syndapin I, a regulator of endocytosis and the actin cytoskeleton. J Biol Chem. 2001;276(28):26622-8.

[154] Modregger J, DiProspero NA, Charles V, Tagle DA, Plomann M. PACSIN 1 interacts with huntingtin and is absent from synaptic varicosities in presymptomatic Huntington's disease brains. Hum Mol Genet. 2002;11(21):2547-58.

[155] Cunha C, Brambilla R, Thomas KL. A simple role for BDNF in learning and memory? Front Mol Neurosci. 2010;3:1.

[156] del Toro D, Canals JM, Gines S, Kojima M, Egea G, Alberch J. Mutant huntingtin impairs the post-Golgi trafficking of brain-derived neurotrophic factor but not its Val66Met polymorphism. J Neurosci. 2006;26(49):12748-57.

[157] Gauthier LR, Charrin BC, Borrell-Pages M, Dompierre JP, Rangone H, Cordelieres FP, et al. Huntingtin controls neurotrophic support and survival of neurons by enhancing BDNF vesicular transport along microtubules. Cell. 2004;118(1):127-38.
[158] Zuccato C, Ciammola A, Rigamonti D, Leavitt BR, Goffredo D, Conti L, et al. Loss of huntingtin-mediated BDNF gene transcription in Huntington's disease. Science. 2001;293(5529):493-8.

[159] Zuccato C, Cattaneo E. Role of brain-derived neurotrophic factor in Huntington's disease. Prog Neurobiol. 2007;81(56):294-330.

[160] Zuccato C, Cattaneo E. Brain-derived neurotrophic factor in neurodegenerative diseases. Nat Rev Neurol. 2009;5(6):311-22.

[161] Altar CA, Cai N, Bliven T, Juhasz M, Conner JM, Acheson $\mathrm{AL}$, et al. Anterograde transport of brain-derived neurotrophic factor and its role in the brain. Nature. 1997;389(6653):856-60

[162] Baquet ZC, Gorski JA, Jones KR. Early striatal dendrite deficits followed by neuron loss with advanced age in the absence of anterograde cortical brain-derived neurotrophic factor. J Neurosci. 2004;24(17):4250-8.

[163] Perez-Navarro E, Canudas AM, Akerund P, Alberch J, Arenas E. Brain-derived neurotrophic factor, neurotrophin-3, and neurotrophin- $4 / 5$ prevent the death of striatal projection neurons in a rodent model of Huntington's disease. J Neurochem. 2000;75(5):2190-9.

[164] Ferrer I, Goutan E, Marin C, Rey MJ, Ribalta T. Brainderived neurotrophic factor in Huntington disease. Brain Res. 2000;866(1-2):257-61.

[165] Gharami K, Xie Y, An JJ, Tonegawa S, Xu B. Brainderived neurotrophic factor over-expression in the forebrain ameliorates Huntington's disease phenotypes in mice. J Neurochem. 2008;105(2):369-79.

[166] Xie Y, Hayden MR, Xu B. BDNF overexpression in the forebrain rescues Huntington's disease phenotypes in YAC128 mice. J Neurosci. 2010;30(44):14708-18.

[167] Gines S, Bosch M, Marco S, Gavalda N, Diaz-Hernandez M, Lucas JJ, et al. Reduced expression of the TrkB receptor in Huntington's disease mouse models and in human brain. Eur J Neurosci. 2006;23(3):649-58.

[168] Gines S, Paoletti P, Alberch J. Impaired TrkB-mediated ERK1/2 activation in huntington disease knock-in striatal cells involves reduced p52/p46 Shc expression. J Biol Chem. 2010;285(28):21537-48.

[169] Lu Y, Christian K, Lu B. BDNF: A key regulator for protein synthesis-dependent LTP and long-term memory? Neurobiol Learn Mem. 2008;89(3):312-23.

[170] Jia Y, Gall CM, Lynch G. Presynaptic BDNF promotes postsynaptic long-term potentiation in the dorsal striatum. $\mathrm{J}$ Neurosci. 2010;30(43):14440-5.

[171] Picconi B, Passino E, Sgobio C, Bonsi P, Barone I, Ghiglieri $\mathrm{V}$, et al. Plastic and behavioral abnormalities in experimental Huntington's disease: A crucial role for cholinergic interneurons. Neurobiol Dis. 2006;22(1):143-52.

[172] Canals JM, Pineda JR, Torres-Peraza JF, Bosch M, MartinIbanez R, Munoz MT, et al. Brain-derived neurotrophic factor regulates the onset and severity of motor dysfunction associated with enkephalinergic neuronal degeneration in Huntington's disease. J Neurosci. 2004;24(35): 7727-39.

[173] Gambazzi L, Gokce O, Seredenina T, Katsyuba E, Runne $\mathrm{H}$, Markram H, et al. Diminished activity-dependent brainderived neurotrophic factor expression underlies cortical neuron microcircuit hypoconnectivity resulting from exposure to mutant huntingtin fragments. J Pharmacol Exp Ther. 2010;335(1):13-22.

[174] Simmons DA, Mehta RA, Lauterborn JC, Gall CM, Lynch $\mathrm{G}$. Brief ampakine treatments slow the progression of 
Huntington's disease phenotypes in R6/2 mice. Neurobiol Dis. 2011;41(2):436-44.

[175] Reichardt LF. Neurotrophin-regulated signalling pathways. Philos Trans R Soc Lond B Biol Sci. 2006;361(1473):154564.

[176] Saavedra A, Garcia-Martinez JM, Xifro X, Giralt A, TorresPeraza JF, Canals JM, et al. PH domain leucine-rich repeat protein phosphatase 1 contributes to maintain the activation of the PI3K/Akt pro-survival pathway in Huntington's disease striatum. Cell Death Differ. 2010;17(2):32435.

[177] Saavedra A, Giralt A, Rue L, Xifro X, Xu J, Ortega Z, et al. Striatal-enriched protein tyrosine phosphatase expression and activity in Huntington's disease: A STEP in the resistance to excitotoxicity. J Neurosci. 2011;31(22):8150-62.

[178] Ernfors P, Bramham CR. The coupling of a trkB tyrosine residue to LTP. Trends Neurosci. 2003;26(4):171-3.

[179] Minichiello L. TrkB signalling pathways in LTP and learning. Nat Rev Neurosci. 2009;10(12):850-60.

[180] Kennedy MB, Beale HC, Carlisle HJ, Washburn LR. Integration of biochemical signalling in spines. Nat Rev Neurosci. 2005;6(6):423-34.

[181] Mansuy IM, Shenolikar S. Protein serine/threonine phosphatases in neuronal plasticity and disorders of learning and memory. Trends Neurosci. 2006;29(12):679-86.

[182] Mayford M. Protein kinase signaling in synaptic plasticity and memory. Curr Opin Neurobiol. 2007;17(3):313-7.

[183] Saavedra A, Alberch J, Perez-Navarro E. Don't Take Away My P: Phosphatases as Therapeutic Targets in Huntington's Disease. Huntington's Disease - Core Concepts and Current Advances, 465-494. 2012. InTech. Ref Type: Generic.

[184] Xifro X, Giralt A, Saavedra A, Garcia-Martinez JM, DiazHernandez M, Lucas JJ, et al. Reduced calcineurin protein levels and activity in exon-1 mouse models of Huntington's disease: Role in excitotoxicity. Neurobiol Dis. 2009;36(3):461-9.

[185] Malleret G, Haditsch U, Genoux D, Jones MW, Bliss TV, Vanhoose AM, et al. Inducible and reversible enhancement of learning, memory, and long-term potentiation by genetic inhibition of calcineurin. Cell. 2001;104(5):675-86.

[186] Mansuy IM, Mayford M, Jacob B, Kandel ER, Bach ME. Restricted and regulated overexpression reveals calcineurin as a key component in the transition from short-term to longterm memory. Cell. 1998;92(1):39-49.

[187] Monti B, Berteotti C, Contestabile A. Dysregulation of memory-related proteins in the hippocampus of aged rats and their relation with cognitive impairment. Hippocampus. 2005:15(8):1041-9.

[188] Riedel G. If phosphatases go up, memory goes down. Cell Mol Life Sci. 1999;55(4):549-53.

[189] Zeng H, Chattarji S, Barbarosie M, Rondi-Reig L, Philpot BD, Miyakawa $\mathrm{T}$, et al. Forebrain-specific calcineurin knockout selectively impairs bidirectional synaptic plasticity and working/episodic-like memory. Cell. 2001;107(5):617-29.

[190] Goto S, Matsukado Y, Miyamoto E, Yamada M. Morphological characterization of the rat striatal neurons expressing calcineurin immunoreactivity. Neuroscience. 1987;22(1):189-201.

[191] Hernandez-Espinosa D, Morton AJ. Calcineurin inhibitors cause an acceleration of the neurological phenotype in a mouse transgenic for the human Huntington's disease mutation. Brain Res Bull. 2006;69(6):669-79.

[192] Lievens JC, Woodman B, Mahal A, Bates GP. Abnormal phosphorylation of synapsin I predicts a neuronal transmis- sion impairment in the R6/2 Huntington's disease transgenic mice. Mol Cell Neurosci. 2002;20(4):638-48.

[193] Metzler M, Gan L, Mazarei G, Graham RK, Liu L, Bissada $\mathrm{N}$, et al. Phosphorylation of huntingtin at Ser421 in YAC128 neurons is associated with protection of YAC128 neurons from NMDA-mediated excitotoxicity and is modulated by PP1 and PP2A. J Neurosci. 2010;30(43):14318-29.

[194] Pineda JR, Pardo R, Zala D, Yu H, Humbert S, Saudou F. Genetic and pharmacological inhibition of calcineurin corrects the BDNF transport defect in Huntington's disease. Mol Brain. 2009;2:33.

[195] Shimizu K, Okada M, Nagai K, Fukada Y. Suprachiasmatic nucleus circadian oscillatory protein, a novel binding partner of K-Ras in the membrane rafts, negatively regulates MAPK pathway. J Biol Chem. 2003;278(17):14920-5.

[196] Shimizu K, Phan T, Mansuy IM, Storm DR. Proteolytic degradation of SCOP in the hippocampus contributes to activation of MAP kinase and memory. Cell. 2007;128(6):1219-29.

[197] Fitzpatrick CJ, Lombroso PJ. The role of striatal-enriched protein tyrosine phosphatase (STEP) in cognition. Front Neuroanat. 2011;5:47.

[198] Lombroso PJ, Murdoch G, Lerner M. Molecular characterization of a protein-tyrosine-phosphatase enriched in striatum. Proc Natl Acad Sci U S A. 1991;88(16):7242-6.

[199] Boulanger LM, Lombroso PJ, Raghunathan A, During MJ, Wahle P, Naegele JR. Cellular and molecular characterization of a brain-enriched protein tyrosine phosphatase. $\mathrm{J}$ Neurosci. 1995;15(2):1532-44.

[200] Braithwaite SP, Paul S, Nairn AC, Lombroso PJ. Synaptic plasticity: One STEP at a time. Trends Neurosci. 2006;29(8):452-8.

[201] Li S, Tian X, Hartley DM, Feig LA. Distinct roles for Ras-guanine nucleotide-releasing factor 1 (Ras-GRF1) and Ras-GRF2 in the induction of long-term potentiation and long-term depression. J Neurosci. 2006;26(6):1721-9.

[202] Abel T, Nguyen PV. Regulation of hippocampus-dependent memory by cyclic AMP-dependent protein kinase. Prog Brain Res. 2008;169:97-115.

[203] Ariano MA, Aronin N, DiFiglia M, Tagle DA, Sibley DR, Leavitt BR, et al. Striatal neurochemical changes in transgenic models of Huntington's disease. J Neurosci Res. 2002;68(6):716-29.

[204] Ariano MA, Wagle N, Grissell AE. Neuronal vulnerability in mouse models of Huntington's disease: Membrane channel protein changes. J Neurosci Res. 2005;80(5):634-45.

[205] Colbran RJ, Brown AM. Calcium/calmodulin-dependent protein kinase II and synaptic plasticity. Curr Opin Neurobiol. 2004;14(3):318-27.

[206] Lisman J, Schulman H, Cline H. The molecular basis of CaMKII function in synaptic and behavioural memory. Nat Rev Neurosci. 2002;3(3):175-90.

[207] Deckel AW, Gordinier A, Nuttal D, Tang V, Kuwada C, Freitas R, et al. Reduced activity and protein expression of NOS in R6/2 HD transgenic mice: Effects of L-NAME on symptom progression. Brain Res. 2001;6;919(1):70-81.

[208] Deckel AW, Elder R, Fuhrer G. Biphasic developmental changes in $\mathrm{Ca} 2+/$ calmodulin-dependent proteins in $\mathrm{R} 6 / 2$ Huntington's disease mice. Neuroreport. 2002;13(5):70711.

[209] Li SH, Li XJ. Huntingtin-protein interactions and the pathogenesis of Huntington's disease. Trends Genet. 2004;20(3):146-54.

[210] Sugars KL, Rubinsztein DC. Transcriptional abnormalities in Huntington disease. Trends Genet. 2003;19(5):233-8. 
[211] Barco A, Pittenger C, Kandel ER. CREB, memory enhancement and the treatment of memory disorders: Promises, pitfalls and prospects. Expert Opin Ther Targets. 2003;7(1):101-14.

[212] Kandel ER. The molecular biology of memory storage: A dialog between genes and synapses. Biosci Rep. 2001;21(5):565-611.

[213] Bourtchuladze R, Frenguelli B, Blendy J, Cioffi D, Schutz G, Silva AJ. Deficient long-term memory in mice with a targeted mutation of the cAMP-responsive element-binding protein. Cell. 1994;79(1):59-68.

[214] Won J, Silva AJ. Molecular and cellular mechanisms of memory allocation in neuronetworks. Neurobiol Learn Mem. 2008;89(3):285-92.

[215] Altarejos JY, Montminy M. CREB and the CRTC coactivators: Sensors for hormonal and metabolic signals. Nat Rev Mol Cell Biol. 2011;12(3):141-51.

[216] Lonze BE, Ginty DD. Function and regulation of CREB family transcription factors in the nervous system. Neuron. 2002;35(4):605-23.

[217] Chuang DM, Leng Y, Marinova Z, Kim HJ, Chiu CT. Multiple roles of HDAC inhibition in neurodegenerative conditions. Trends Neurosci. 2009;32(11):591-601.

[218] Sadri-Vakili G, Cha JH. Mechanisms of disease: Histone modifications in Huntington's disease. Nat Clin Pract Neurol. 2006;2(6):330-8.

[219] Alarcon JM, Malleret G, Touzani K, Vronskaya S, Ishii S, Kandel ER, et al. Chromatin acetylation, memory, and LTP are impaired in $\mathrm{CBP}+/-$ mice: A model for the cognitive deficit in Rubinstein-Taybi syndrome and its amelioration. Neuron. 2004;42(6):947-59.

[220] Oliveira AM, Abel T, Brindle PK, Wood MA. Differential role for CBP and p300 CREB-binding domain in motor skill learning. Behav Neurosci. 2006;120(3):724-9.

[221] Ogryzko VV, Schiltz RL, Russanova V, Howard BH, Nakatani Y. The transcriptional coactivators p300 and CBP are histone acetyltransferases. Cell. 1996;87(5):953-9.

[222] Hockly E, Richon VM, Woodman B, Smith DL, Zhou X, Rosa E, et al. Suberoylanilide hydroxamic acid, a histone deacetylase inhibitor, ameliorates motor deficits in a mouse model of Huntington's disease. Proc Natl Acad Sci U S A. 2003;100(4):2041-6.

[223] Fellin T. Communication between neurons and astrocytes: Relevance to the modulation of synaptic and network activity. J Neurochem. 2009;108(3):533-44.

[224] Haydon PG. GLIA: Listening and talking to the synapse. Nat Rev Neurosci. 2001;2(3):185-93.

[225] Santello M, Volterra A. Neuroscience: Astrocytes as aidememoires. Nature. 2010;463(7278):169-70.

[226] Suzuki A, Stern SA, Bozdagi O, Huntley GW, Walker $\mathrm{RH}$, Magistretti PJ, et al. Astrocyte-neuron lactate transport is required for long-term memory formation. Cell. 2011;144(5):810-23.

[227] Schummers J, Yu H, Sur M. Tuned responses of astrocytes and their influence on hemodynamic signals in the visual cortex. Science 2008;320(5883):1638-43.

[228] Shin JY, Fang ZH, Yu ZX, Wang CE, Li SH, Li XJ. Expression of mutant huntingtin in glial cells contributes to neuronal excitotoxicity. J Cell Biol. 2005;171(6):1001-12.

[229] Bradford J, Shin JY, Roberts M, Wang CE, Li XJ, Li S. Expression of mutant huntingtin in mouse brain astrocytes causes age-dependent neurological symptoms. Proc Natl Acad Sci U S A. 2009;106(52):22480-5.

[230] Bradford J, Shin JY, Roberts M, Wang CE, Sheng G, Li S, et al. Mutant huntingtin in glial cells exacerbates neurolog- ical symptoms of Huntington disease mice. J Biol Chem. 2010;285(14):10653-61.

[231] Faideau M, Kim J, Cormier K, Gilmore R, Welch M, Auregan $\mathrm{G}$, et al. In vivo expression of polyglutamine-expanded huntingtin by mouse striatal astrocytes impairs glutamate transport: A correlation with Huntington's disease subjects. Hum Mol Genet. 2010;19(15):3053-67.

[232] Chou SY, Weng JY, Lai HL, Liao F, Sun SH, Tu PH, et al. Expanded-polyglutamine huntingtin protein suppresses the secretion and production of a chemokine (CCL5/RANTES) by astrocytes. J Neurosci. 2008;28(13):3277-90.

[233] Wang DD, Bordey A. The astrocyte odyssey. Prog Neurobiol. 2008;86(4):342-67.

[234] Harris GJ, Codori AM, Lewis RF, Schmidt E, Bedi A, Brandt J. Reduced basal ganglia blood flow and volume in presymptomatic, gene-tested persons at-risk for Huntington's disease. Brain. 1999;122 (Pt 9):1667-78.

[235] Wolf RC, Sambataro F, Vasic N, Wolf ND, Thomann PA, Landwehrmeyer GB, et al. Longitudinal functional magnetic resonance imaging of cognition in preclinical Huntington's disease. Exp Neurol. 2011;231(2):214-22.

[236] Sturrock A, Leavitt BR. The clinical and genetic features of Huntington disease. J Geriatr Psychiatry Neurol. 2010;23(4):243-59.

[237] Venuto CS, McGarry A, Ma Q, Kieburtz K. Pharmacologic approaches to the treatment of Huntington's disease. Mov Disord. 2012;27(1):31-41.

[238] Cubo E, Shannon KM, Tracy D, Jaglin JA, Bernard BA, Wuu $\mathrm{J}$, et al. Effect of donepezil on motor and cognitive function in Huntington disease. Neurology. 2006;67(7):1268-71.

[239] Fernandez HH, Friedman JH, Grace J, Beason-Hazen S. Donepezil for Huntington's disease. Mov Disord. 2000;15(1):173-6

[240] de Tommaso M., Specchio N, Sciruicchio V, Difruscolo O, Specchio LM. Effects of rivastigmine on motor and cognitive impairment in Huntington's disease. Mov Disord. 2004;19(12):1516-8.

[241] de Tommaso M, Difruscolo O, Sciruicchio V, Specchio N, Livrea P. Two years' follow-up of rivastigmine treatment in Huntington disease. Clin Neuropharmacol. 2007;30(1):436.

[242] Rot U, Kobal J, Sever A, Pirtosek Z, Mesec A. Rivastigmine in the treatment of Huntington's disease. Eur J Neurol. 2002;9(6):689-90.

[243] Kieburtz K, McDermott MP, Voss TS, Corey-Bloom J, Deuel LM, Dorsey ER, et al. A randomized, placebocontrolled trial of latrepirdine in Huntington disease. Arch Neurol. 2010;67(2):154-60.

[244] Lee YS, Silva AJ. The molecular and cellular biology of enhanced cognition. Nat Rev Neurosci. 2009;10(2):126-40.

[245] Borrell-Pages M, Canals JM, Cordelieres FP, Parker JA, Pineda JR, Grange G, et al. Cystamine and cysteamine increase brain levels of BDNF in Huntington disease via HSJ1b and transglutaminase. J Clin Invest. 2006;116(5):1410-24.

[246] Apostol BL, Simmons DA, Zuccato C, Illes K, Pallos J, Casale M, et al. CEP-1347 reduces mutant huntingtinassociated neurotoxicity and restores BDNF levels in R6/2 mice. Mol Cell Neurosci. 2008;39(1):8-20.

[247] Duan W, Peng Q, Masuda N, Ford E, Tryggestad E, Ladenheim B, et al. Sertraline slows disease progression and increases neurogenesis in N171-82Q mouse model of Huntington's disease. Neurobiol Dis. 2008;30(3):312-22.

[248] Peng Q, Masuda N, Jiang M, Li Q, Zhao M, Ross CA, et al. The antidepressant sertraline improves the pheno- 
type, promotes neurogenesis and increases BDNF levels in the R6/2 Huntington's disease mouse model. Exp Neurol. 2008;210(1):154-63.

[249] DeMarch Z, Giampa C, Patassini S, Bernardi G, Fusco FR. Beneficial effects of rolipram in the R6/2 mouse model of Huntington's disease. Neurobiol Dis. 2008;30(3):375-87.

[250] Giampa C, Laurenti D, Anzilotti S, Bernardi G, Mennit FS, Fusco FR. Inhibition of the striatal specific phosphodiesterase PDE10A ameliorates striatal and cortical pathology in R6/2 mouse model of Huntington's disease. PLoS One. 2010;5(10):e13417.

[251] Nithianantharajah J, Hannan AJ. Mechanisms mediating brain and cognitive reserve: Experience-dependent neuroprotection and functional compensation in animal models of neurodegenerative diseases. Prog Neuropsychopharmacol Biol Psychiatry. 2011;35(2):331-9.

[252] Spires TL, Grote HE, Varshney NK, Cordery PM, van DA, Blakemore C, et al. Environmental enrichment rescues protein deficits in a mouse model of Huntington's disease, indicating a possible disease mechanism. J Neurosci. 2004;24(9):2270-6.

[253] Zajac MS, Pang TY, Wong N, Weinrich B, Leang LS, Craig JM, et al. Wheel running and environmental enrichment differentially modify exon-specific BDNF expression in the hippocampus of wild-type and pre-motor symptomatic male and female Huntington's disease mice. Hippocampus. 2010;20(5):621-36.

[254] Duan W, Guo Z, Jiang H, Ware M, Li XJ, Mattson MP. Dietary restriction normalizes glucose metabolism and BDNF levels, slows disease progression, and increases survival in huntingtin mutant mice. Proc Natl Acad Sci U S A. 2003;100(5):2911-6.

[255] Zhang F, Wang S, Gan L, Vosler PS, Gao Y, Zigmond MJ, et al. Protective effects and mechanisms of sirtuins in the nervous system. Prog Neurobiol. 2011;95(3):373-95.
[256] Jiang M, Wang J, Fu J, Du L, Jeong H, West T, et al. Neuroprotective role of Sirt1 in mammalian models of Huntington's disease through activation of multiple Sirt1 targets. Nat Med. 2012;18(1):153-8.

[257] Jeong H, Cohen DE, Cui L, Supinski A, Savas JN, Mazzulli JR, et al. Sirt1 mediates neuroprotection from mutant huntingtin by activation of the TORC 1 and CREB transcriptional pathway. Nat Med. 2012;18(1):159-65.

[258] Cayzac S, Delcasso S, Paz V, Jeantet Y, Cho YH. Changes in striatal procedural memory coding correlate with learning deficits in a mouse model of Huntington disease. Proc Natl Acad Sci U S A. 2011;108(22):9280-5.

[259] Pallier PN, Drew CJ, Morton AJ. The detection and measurement of locomotor deficits in a transgenic mouse model of Huntington's disease are task- and protocol-dependent: Influence of non-motor factors on locomotor function. Brain Res Bull. 2009;78(6):347-55.

[260] Carter RJ, Lione LA, Humby T, Mangiarini L, Mahal A, Bates GP, et al. Characterization of progressive motor deficits in mice transgenic for the human Huntington's disease mutation. J Neurosci. 1999;19(8):3248-57.

[261] Fine EM, Delis DC, Wetter SR, Jacobson MW, Hamilton JM, Peavy G, et al. Identifying the "source" of recognition memory deficits in patients with Huntington's disease or Alzheimer's disease: Evidence from the CVLT-II. J Clin Exp Neuropsychol. 2008;30(4):463-70.

[262] Marcora E, Kennedy MB. The Huntington's disease mutation impairs Huntingtin's role in the transport of NF-kappaB from the synapse to the nucleus. Hum Mol Genet. 2010;19(22):4373-84. 